\title{
Influence of Tropical Climate Parameters on Properties of Acid Sulfate Soils for Sustainable Oil Palm Cultivation
}

\author{
Pattamit Sasirat, Irb Kheoruenromne (D), Anchalee Suddhiprakarn, \\ and Somchai Anusontpornperm \\ Department of Soil Science, Faculty of Agriculture, Kasetsart University, Bangkok 10900, Thailand \\ Correspondence should be addressed to Irb Kheoruenromne; irbs@ku.ac.th
}

Received 4 July 2019; Accepted 5 September 2019; Published 14 November 2019

Academic Editor: Maria Serrano

Copyright (c) 2019 Pattamit Sasirat et al. This is an open access article distributed under the Creative Commons Attribution License, which permits unrestricted use, distribution, and reproduction in any medium, provided the original work is properly cited.

\begin{abstract}
To promote effective oil palm plantation and environmental sustainability, this research assessed influence of climatic parameters on physicochemical properties of Thai acid sulfate soils (ASSs). ASSs under oil palm planting areas (Topsoil: Ap, Subsoil-1: Ap$60 \mathrm{~cm}$, Subsoil-2: $60-100 \mathrm{~cm}$, and Rootzone: sum of the three depth levels) and historical climate data in tropical savanna and tropical monsoon were investigated. Stepwise approach of multiple regression analysis from component defining variable of principal component analysis revealed that, in tropical savanna, daily solar radiation influenced clay content $(p<0.05)$ in Topsoil, cation exchange capacity $(p<0.05)$ in Subsoil- 1 , soil $\mathrm{pH}$ by water $(p<0.01)$ in Subsoil-2, and silt content $(p<0.001)$ in Rootzone. In tropical monsoon, daily solar radiation influenced exchangeable magnesium $(p<0.01)$ in Subsoil-2, and exchangeable sodium $(p<0.01)$ and silt content $(p<0.01)$ in Rootzone. We concluded that daily solar radiation is the most influential climatic parameter on soil properties due to the transport of heat in soils, whereas particle size distribution is mostly influenced by climatic parameters due to their clay and silt fractions. OPP in ASSs under these climates should include management of water usage by using raised beds with irrigation canals, considering the rooting depth and depth of acidic horizon before applying fertilizer or amendment and liming along with integrated organic material management to raise soil $\mathrm{pH}$.
\end{abstract}

\section{Introduction}

Oil palm (Elaeis guineensis Jacq.) is a native of Central Africa, but it can thrive successfully as a commercial crop in tropical lowland areas [1], and it has been considered as the most efficient oilseed crop in the world [2]. In addition, the global market of biodiesel and aviation biofuel has been increasing continually that creates opportunities in Southeast Asia, including Thailand to be major producers, consumers, and exporters [3]. Unfortunately, a plan in Thailand to extend oil palm planting areas in the Southern and Eastern regions for alternative energy was restricted because most area has already been used under productive agriculture [4]. Regarding this, the Land Development Department of Thailand had proposed the main target planting area which was not under productive agriculture [5].
Acid sulfate soils (ASSs) are mostly formed in coastal plains in the tropics and generally less in the temperate zones [6]. The soils are found in South Asia, Southeast Asia, and East Asia of the Tropics [7] with the larger part in Indonesia, Thailand, and Vietnam [8]. Thai ASSs are widespread in some parts of country, especially in the Central Plain (CP) with other small areas in the Southeast Coast (SC) and peninsular regions [9].

Acid sulfate soils have been posing problems for crop production management because of their severe acidity. These soils affect oil palm yields by depth of acidic horizon where it occurs within 60 centimeters of soil surface $[6,10]$. Nevertheless, oil palm is moderately tolerant to soil acidity and can be grown on ASS under proper management practices [11] which consider parameters affecting growth performance [12]. 
The Department of Alternative Energy Development and Efficiency of Thailand estimated the potential ability of palm oil for biodiesel production at 14 million liters per day in 2036 [13]. The planting areas have been expanding into the northern and northeastern regions [14] even though these regions were never planted in the past due to their low climate suitability that requires an intensive treatment and irrigation supply [15]. These lead to high greenhouse gas emissions and water scarcity footprint per ton of fresh fruit bunch (FFB) products [15]. Oil palm plantation areas are somewhat limited by climatic conditions $[15,16]$, especially oil palm in ASS can be affected by droughts in an El Nino year. The yields are reduced due to severe acidity from low water level [17]. Therefore, improving oil palm productivity should take into consideration the control and management of climatic parameters [18]. However, it is difficult to determine climatic limitations in different regions or countries by comparing the FFB yields because many other parameters may influence this comparison [17]. The main climatic elements affecting growth and yield of oil palms are temperature, solar radiation intensity and duration, rainfall, atmospheric vapor pressure deficit, evaporation rate, and wind speed $[19,20]$.

The suitability of soil and climate combinations for oil palm development can be calculated by using Surre [21] method [22] which has been continuously used in oil palm industry to calculate water deficit [23-25]. Seasonal water deficit is considered as the most important climatic parameter affecting oil palm yields [17]. The yields will be lost about $10 \%$ for every $100 \mathrm{~mm}$ increase in water deficit [26] and $20 \%$ if it exists for 3 years continually [27]. The FFB yield will be reduced between $10 \%$ and $20 \%$ by water deficit depending on each soil's quality [23, 28]. Therefore, the promotion for expanding oil palm planting areas must consider environmental sustainability based on suitability of land and climate along with good practices for productivity improvement [15]. In addition, the rooting depth should be at least $100 \mathrm{~cm}$ as it is important for nutrition, water uptake, and anchoring in the ground [17]. To support the increasing demand and consider environmental sustainability, there is a need to analyze the suitability of climate and ASS and their influence in CP and SC so as to devise an efficient plan for sustainable oil palm cultivation in tropical setting including Thailand.

\section{Materials and Methods}

2.1. Soil Sampling. Twenty study sites of ASS under oil palm planting areas in CP (10 sites) and SC (10 sites) of Thailand were examined (Table 1 and Figure 1). These soils have developed under tropical savanna and tropical monsoon climates, respectively. The soils in CP were classified by soil taxonomy [29] as Typic Sulfaquepts and Sulfic Endoaquepts, whereas the soils in SC were classified as Typic Sulfaquepts. These soils in both CP and SC were classified by World Reference Base [30] as Thionic Gleysols. The soils were collected during September and October in 2013 by hand auger to a maximum depth of $100 \mathrm{~cm}$ consisting of Topsoil (Ap), Subsoil-1 (Ap-60 cm), and Subsoil-2 $(60-100 \mathrm{~cm})$, whereas Rootzone $(0-100 \mathrm{~cm})$ was the sum of the three depth levels. The Topsoil depth varies in the range of $18-30 \mathrm{~cm}$ in CP and $14-26 \mathrm{~cm}$ in SC. In order to minimize oxidation of sulfidic materials, soil samples were kept in sealed plastic bags and cooled to $4{ }^{\circ} \mathrm{C}$ in an ice container during transportation from field to laboratory.

2.2. Climatic Data. Historical climate data downloaded from the "WorldClim version 2" database (http://www.worldclim. org/version2) [31] for the period 1970-2000 consist of monthly minimum temperature, maximum temperature, mean temperature, precipitation, solar radiation, wind speed, and water vapor pressure. The spatial resolutions with 30 seconds $\left(\sim 1 \mathrm{~km}^{2}\right)$ containing 12 GeoTiff files, one for each month of the year, were used in this study.

2.3. Soil Analysis. Physicochemical properties of soil samples were determined for field-moist conditions but are reported on an oven-dried $\left(105^{\circ} \mathrm{C}\right)$ basis. The methods of physicochemical analysis are summarized in Table 2.

2.4. Data Analysis. Monthly potential evapotranspiration (ETP) was calculated based on Hargreaves and Semani [43] equation following Läderach et al. [44]:

$$
\mathrm{ETP}=0.0023 \times R_{\mathrm{a}} \times(T-t)^{0.5} \times\left(t_{\mathrm{m}}+17.8\right),
$$

where ETP = evapotranspiration $\left(\mathrm{mm} \cdot \mathrm{day}^{-1}\right), R_{\mathrm{a}}=$ extraterrestrial solar radiation expressed in water equivalent $\left(\mathrm{mm} \cdot \mathrm{day}^{-1}\right)$, $T-t=$ different between monthly maximum and minimum mean temperature $\left({ }^{\circ} \mathrm{C}\right)$, and $t_{\mathrm{m}}=$ mean air temperature $\left({ }^{\circ} \mathrm{C}\right)$. $R_{\mathrm{a}}$ was converted into water equivalent $\left(\mathrm{mm} \cdot \mathrm{day}^{-1}\right)$ with $1 \mathrm{~mm} \cdot \mathrm{day}^{-1}=2.45 \mathrm{MJ} \cdot \mathrm{m}^{-2} \cdot$ day $^{-1}[45]$.

ETP was converted to monthly water balance $(B)$ based on the Surre (1968) equation by following Rhebergen et al. [25]:

$$
B=S_{\text {res }}+\mathrm{PPT}_{\mathrm{m}}-\mathrm{ETP},
$$

where $B=$ monthly water balance $(\mathrm{mm}), S_{\text {res }}=$ residual soil water from previous month $(\mathrm{mm}), \mathrm{PPT}_{\mathrm{m}}=$ monthly precipitation $(\mathrm{mm})$, and ETP $=$ monthly potential evapotranspiration ( $\mathrm{mm})$.

Available water capacity (AWC) for each soil texture class (Topsoil, Subsoil-1, and Subsoil-2) was calculated based on the Epebinu and Nwadialo equation [33]:

$$
\mathrm{AWC}=0.93+0.54 S+0.13 C,
$$

where $S=\operatorname{silt}(\%)$ and $C=\operatorname{clay}(\%)$. The sum of AWC was the maximum amount of available soil water in the top $100 \mathrm{~cm}$. The excess of water was assumed to be lost as drainage or runoff; water deficit was indicated by the negative values of $B^{\prime} S_{\text {res }}$ of the following month was set to zero; $S_{\text {res }}$ was set to the maximum (total possible AWC) if it was greater than the sum of AWC, the sum of all negative monthly water balances was annual water deficit [25]. 
TABLe 1: Site descriptions of acid sulfate soils under oil palm planting areas in Central Plain and Southeast Coast.

\begin{tabular}{|c|c|c|c|c|c|}
\hline ID & Region $^{\mathrm{a}}$ & Province & Elevation $(\mathrm{m}) \mathrm{MSL}^{\mathrm{b}}$ & Soil series $^{\mathrm{c}}$ & Latitude, longitude \\
\hline 1 & $\mathrm{CP}$ & Pathum Thani & 4 & $\mathrm{Ok}$ & $14.16516,100.78867$ \\
\hline 2 & $\mathrm{CP}$ & Saraburi & 5 & Rs & $14.25838,100.85240$ \\
\hline 3 & $\mathrm{CP}$ & Nakhon Nayok & 5 & Rs-a & $14.25973,100.96311$ \\
\hline 4 & $\mathrm{CP}$ & Nakhon Nayok & 3 & Rs-a & $14.25081,100.96831$ \\
\hline 5 & $\mathrm{CP}$ & Nakhon Nayok & 3 & Rs-a & $14.24884,100.96704$ \\
\hline 6 & $\mathrm{CP}$ & Saraburi & 4 & Rs-a & $14.26024,100.90631$ \\
\hline 7 & $\mathrm{CP}$ & Saraburi & 5 & Rs-a & $14.26008,100.91031$ \\
\hline 8 & $\mathrm{CP}$ & Nakhon Nayok & 7 & Rs-a & $14.27255,100.96386$ \\
\hline 9 & $\mathrm{CP}$ & Nakhon Nayok & 6 & Rs-a & $14.28120,100.97413$ \\
\hline 10 & $\mathrm{CP}$ & Nakhon Nayok & 4 & Rs-a & $14.28188,100.96186$ \\
\hline 11 & SC & Chanthaburi & 11 & $\mathrm{Ca}$ & $12.75267,101.86470$ \\
\hline 12 & SC & Chanthaburi & 4 & $\mathrm{Ca}$ & $12.61623,101.93433$ \\
\hline 13 & SC & Chanthaburi & 4 & $\mathrm{Ca}$ & $12.61759,101.93652$ \\
\hline 14 & SC & Chanthaburi & 2 & $\mathrm{Ca}$ & $12.63581,101.94968$ \\
\hline 15 & SC & Chanthaburi & 3 & $\mathrm{Ca}$ & $12.62373,101.96834$ \\
\hline 16 & SC & Chanthaburi & 2 & $\mathrm{Ca}$ & $12.45328,102.21149$ \\
\hline 17 & SC & Chanthaburi & 1 & $\mathrm{Ca}$ & $12.42625,102.27559$ \\
\hline 18 & SC & Chanthaburi & 2 & $\mathrm{Ca}$ & $12.42857,102.27592$ \\
\hline 19 & SC & Chanthaburi & 4 & $\mathrm{Ca}$ & $12.39205,102.35682$ \\
\hline 20 & SC & Chanthaburi & 3 & $\mathrm{Ca}$ & $12.39916,102.29920$ \\
\hline
\end{tabular}

${ }^{a} \mathrm{CP}=$ Central Plain; $\mathrm{SC}=$ Southeast Coast. ${ }^{\mathrm{b}} \mathrm{MSL}=$ mean sea level. ${ }^{\mathrm{c}} \mathrm{Ok}=$ Ongkharak series, Rs $=$ Rangsit series, Rs-a $=$ Rangsit series-very acid phase, and $\mathrm{Ca}=$ Cha-am series.

2.5. Climate and Soil Suitability Evaluation for Oil Palm. We used climatic suitability classification of Goh [19], water deficit suitability classification of Rhebergen et al. [25], and ideal climate requirement of Hartley [46] to evaluate climatic suitability (Table 3). Also, we used soil limitation of Shamshuddin et al. [47] and soil nutrient status of Goh [48] to evaluate soil suitability (Table 4 ).

2.6. Statistical Analysis. The climate and ASS data were analyzed by using principal components analysis (PCA) and multiple regression analysis (MRA) from SPSS (version 24) for Windows. The PCA was performed to reduce the set of climate and soil variables; component defining variable (CDV) selected the variables with the highest principal component loading from the rotated principal components, and stepwise approach of MRA determined the relative effects of climatic parameters on physicochemical properties of ASSs.

\section{Results}

3.1. Climatic Parameters. The climatic parameters of CP and SC are shown in Table 5. Climate suitability for sustainable oil palm was considered by climatic suitability classification of Goh [19]. Figure 2 shows the climatic conditions of CP and SC classified as currently unsuitable and suitable annual precipitations, highly suitable annual mean temperatures, suitable daily solar radiations, and highly suitable annual wind speeds, respectively. Also, by water deficit suitability classification of Rhebergen et al. [25], Figure 3(a) shows CP is favorable, while SC is optimal. In addition, Figure 3(b) shows CP and SC are in the ranges of ideal climate requirement of Hartley [46] with their annual maxima temperatures and minima temperatures, respectively.
3.2. Physicochemical Properties of ASS. Physicochemical properties of ASS under oil palm planting areas in $\mathrm{CP}$ and SC are shown in Tables 6 and 7. The median $\mathrm{pH}_{1: 1}-\mathrm{H}_{2} \mathrm{O}$ (soil $\mathrm{pH}$ by water) of $\mathrm{CP}$ are low at all depth levels, whereas the median $\mathrm{pH}_{1: 1}-\mathrm{H}_{2} \mathrm{O}$ of SC are low but slightly increased with depth from Topsoil to Subsoil-2 (Table 7). The median TN (total nitrogen) of CP are high but slightly decreased with depth from Topsoil to Subsoil2, whereas the median TN of SC are high and slightly increased with depth from Topsoil to Subsoil2 (Table 7). The median Avail-P (available phosphorus) of CP are high in Topsoil but low in Subsoill and Subsoil2, whereas the median Avail-P of SC are low at all depth levels (Table 7). The median Exch-K (exchangeable potassium) of CP are high at all depth levels, whereas the median Exch-K of SC are low but slightly increased with depth from Topsoil to Subsoil2 (Table 7). The median Exch$\mathrm{Mg}$ (exchangeable magnesium) of CP are high at all depth levels, whereas the median Exch-Mg of SC are high and slightly increased with depth from Topsoil to Subsoil2 (Table 7).

3.3. Result of PCA on Climatic Parameters. The result of PCA based on the correlation matrix analysis with Varimax rotation indicated 2 principal components (PCs) with the extraction of eigenvalues greater than 1 of $\mathrm{CP}$ and SC (Table S1). The extracted components had overall cumulative variances about $88.3 \%$ and $90.1 \%$, respectively, based on the significant variables which factor loading $\geq 0.7$ and the concept of CDV which selected the highest component loading of each principal component. The result indicated the main climate parameters that influence the physicochemical properties of ASSs (Table S1). The main climatic parameters of $\mathrm{CP}$ were daily solar radiation and annual water deficit, while those for SC were annual water vapor 


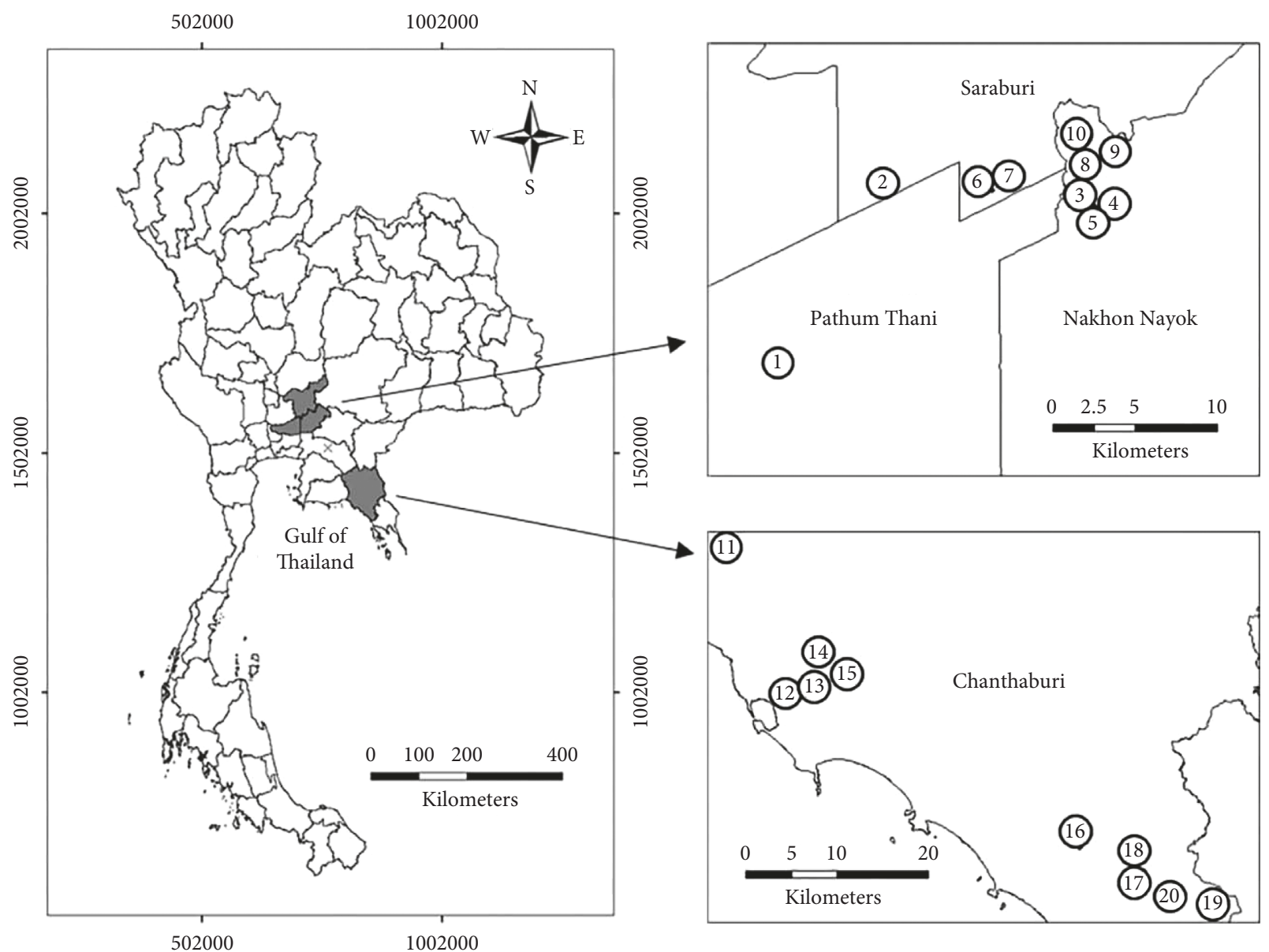

FIGURE 1: Sampling locations of acid sulfate soils under oil palm planting areas in Central Plain (ID 1-10) and Southeast Coast (ID 11-20) regions, Thailand.

pressure, annual minimum temperature, and daily solar radiation (the values of annual water vapor pressure and annual minimum temperature were equal).

3.4. Results of PCA on Physicochemical Properties of ASSs. Likewise, the PCA results of CP and SC had overall cumulative variances of the extracted components of Topsoil about $90.4 \%$ and $95.4 \%$, Subsoil-1 about $93.0 \%$ and $95.6 \%$, Subsoil-2 about $91.3 \%$ and $92.6 \%$, and Rootzone about $90.7 \%$ and $90.4 \%$, respectively. The CDV results indicated the main soil properties of each area. The Topsoil of CP were Exch-Ca (exchangeable calcium), clay content, CEC, and Acid-BC (acid buffering capacity), while the Topsoil of SC were Extr- $\mathrm{SO}_{4}{ }^{2-}$ (extractable sulfate), Exch-K, silt content, clay content, and Exch-Ca (Table S2). The Subsoil-1 of $\mathrm{CP}$ were Exch-Ca, CEC, Exch-Na (exchangeable sodium), $\mathrm{pH}_{1: 1}-\mathrm{H}_{2} \mathrm{O}_{2}$ (soil $\mathrm{pH}$ by hydrogen peroxide), and $\mathrm{EC}$, while the Subsoil-1 of SC were Acid-BC, Exch-Na, Avail-P, silt content, and clay content (Table S3). The Subsoil-2 of CP were $\mathrm{pH}_{1: 1}-\mathrm{H}_{2} \mathrm{O}, \mathrm{TN}$, Exch-Mg, Extr-SO ${ }_{4}{ }^{2-}$, and sand content, while the Subsoil-2 of SC were Exch-Mg, AWC, Acid-BC, Avail-P, and EA (Table S4). The Rootzone of CP were Exch-Ca, TN, silt content, EC, sand content, and Acid-
BC, while the Rootzone of SC were Acid-BC, Exch-Na, silt content, clay content, Avail-P, and TN (Table S5).

3.5. Influence of Climate on Physicochemical Properties of ASSs. Stepwise MRA was used to select variables of climatic parameters and physicochemical properties from CDV results in order to determine the effects of climatic parameters on physicochemical properties of ASS under oil palm planting areas in CP and SC (Table 8).

In $\mathrm{CP}$, the results showed (i) clay content $(F=5.46$, $p<0.05)$ in Topsoil, CEC $(F=9.58, p<0.05)$ in Subsoil-1, $\mathrm{pH}_{1: 1}-\mathrm{H}_{2} \mathrm{O}(F=12.79, p<0.01)$ in Subsoil-2, and silt content $(F=31.59, p<0.001)$ in Rootzone, were significantly influenced by daily solar radiation; (ii) Acid-BC in Rootzone was significantly influenced by annual water deficit. In other words, (i) daily solar radiation accounted for $33 \%$ of clay content in Topsoil, 49\% of CEC in Subsoil-1, 57\% of $\mathrm{pH}_{1: 1^{-}}$ $\mathrm{H}_{2} \mathrm{O}$ in Subsoil-2, and $51 \%$ of silt content in Rootzone; (ii) annual water deficit accounted for $11 \%$ of Acid-BC in Rootzone.

In SC, the results showed (i) clay content $(F=8.55$, $p<0.05)$ in Topsoil, AWC $(F=7.75, p<0.05)$ in Subsoil-2 and clay content $(F=28.23, p<0.001)$ in Rootzone were 
TABLE 2: Method of soil analyses.

\begin{tabular}{|c|c|c|c|}
\hline No. & Analysis & Method & Reference \\
\hline \multicolumn{4}{|c|}{ Physical analysis } \\
\hline 1 & Particle size analysis (sand, silt, and clay) & Pipette method & Kilmer and Alexander [32] \\
\hline 2 & Available water capacity (AWC) & $0.93+0.54$ silt +0.13 clay & Epebinu and Nwadialo [33] \\
\hline \multicolumn{4}{|c|}{ Chemical analysis } \\
\hline 3 & Soil $\mathrm{pH}\left(\mathrm{pH}_{1: 1}-\mathrm{H}_{2} \mathrm{O}\right.$ and $\left.\mathrm{pH}_{1: 1}-\mathrm{H}_{2} \mathrm{O}_{2}\right)$ & $1: 1$ soil to solution in $\mathrm{H}_{2} \mathrm{O}$ and $6 \% \mathrm{H}_{2} \mathrm{O}_{2}$ & $\begin{array}{l}\text { National Soil Survey Center } \\
\text { [34] }\end{array}$ \\
\hline 4 & Electrical conductivity (EC) & Extract of saturated soil to water & $\begin{array}{l}\text { National Soil Survey Center } \\
\text { [34] }\end{array}$ \\
\hline 5 & Organic carbon (OC) & Walkley and Black method & Nelson and Sommers [35] \\
\hline 6 & Total nitrogen $(\mathrm{TN})$ & Kjeldahl method & Bremner [36] \\
\hline 7 & $\mathrm{pH}$ buffering capacity (Acid-BC and Base-BC) & Acid-base titration & $\begin{array}{c}\text { Natscher and Schwertmann } \\
\text { [37] }\end{array}$ \\
\hline 8 & Cation exchange capacity (CEC) & $\begin{array}{l}\text { Saturating the exchange site and displacing by } \\
\qquad 1 \mathrm{M} \mathrm{NH}_{4} \mathrm{OAc}\end{array}$ & Chapman [38] \\
\hline 9 & $\begin{array}{c}\text { Exchangeable bases (Exch-Ca, Exch-Mg, Exch-K, } \\
\text { and Exch-Na) }\end{array}$ & $1 \mathrm{M} \mathrm{NH}_{4} \mathrm{OAc}$ at $\mathrm{pH} 7$ extraction & Thomas [39] \\
\hline 10 & Extractable acidity (EA) & $\begin{array}{c}\text { Barium chloride-triethanolamine at } \mathrm{pH} 8.2 \\
\text { extraction }\end{array}$ & Peech $[40]$ \\
\hline 11 & Available phosphorus (Avail-P) & Bray II method & Bray and Kurtz [41] \\
\hline 12 & Available potassium (Avail-K) & $1 \mathrm{M} \mathrm{NH}_{4} \mathrm{OAc}$ at $\mathrm{pH} 7.0$ extraction & $\begin{array}{l}\text { National Soil Survey Center } \\
\text { [34] }\end{array}$ \\
\hline 13 & Extractable aluminum (Extr-Al) & $1 \mathrm{M} \mathrm{KCl}$ extr & $\begin{array}{c}\text { National Soil Survey Center } \\
\text { [34] }\end{array}$ \\
\hline 14 & Base saturation percentage (BSP) & $\begin{array}{l}\text { The sum of bases extracted by } \mathrm{NH}_{4} \mathrm{OAc} \text { at } \mathrm{pH} 7.0 \text {, } \\
\text { divided by CEC, and multiplied by } 100\end{array}$ & $\begin{array}{l}\text { National Soil Survey Center } \\
{[34]}\end{array}$ \\
\hline 15 & Extractable sulfate $\left(\right.$ Extr- $\left.-\mathrm{SO}_{4}{ }^{2-}\right)$ & $0.008 \mathrm{M} \mathrm{Ca}\left(\mathrm{H}_{2} \mathrm{PO} 4\right)_{2} \bullet \mathrm{H}_{2} \mathrm{O}$ extraction & Combs et al. [42] \\
\hline
\end{tabular}

TABLE 3: Climatic suitability evaluation for oil palm.

\begin{tabular}{|c|c|c|c|c|c|}
\hline $\begin{array}{l}\text { Climatic suitability classification }^{\mathrm{a}} \\
(\text { Goh }[19])<\end{array}$ & $\begin{array}{l}\text { Highly } \\
\text { suitable }\end{array}$ & Suitable & $\begin{array}{l}\text { Moderately } \\
\text { suitable }\end{array}$ & $\begin{array}{l}\text { Currently } \\
\text { unsuitable }\end{array}$ & $\begin{array}{c}\text { Permanently } \\
\text { unsuitable }\end{array}$ \\
\hline PPT (mm year ${ }^{-1}$ ) & $2000-2500$ & $\begin{array}{l}1700-2000 \\
2500-3000\end{array}$ & $\begin{array}{l}1400-1700 \\
3000-4000\end{array}$ & $\begin{array}{l}1100-1400 \\
4000-5000\end{array}$ & $>5000$ \\
\hline MeanT $\left({ }^{\circ} \mathrm{C}\right)$ & $26-29$ & $23-26,29-32$ & $20-23,32-34$ & $17-20,34-36$ & $<20,>30$ \\
\hline $\mathrm{SR}\left(\mathrm{MJ} \cdot \mathrm{m}^{-2}\right)$ & $16-17$ & $14-16,17-19$ & $11-14,19-21$ & $8-11,21-23$ & $<8$ \\
\hline WS $\left(\mathrm{m} \cdot \mathrm{s}^{-1}\right)$ & $<10$ & $10-15,14-16$ & $11-14,15-25$ & $8-11,25-40$ & $>40$ \\
\hline $\begin{array}{l}\text { Water deficit suitability classification } \\
\text { (Rhebergen et al. [25]) }\end{array}$ & Optimal & Favorable & Suitable & Unsuitable & \\
\hline $\mathrm{WD}(\mathrm{mm})$ & $<150$ & $<250$ & $<400$ & $>400$ & \\
\hline Ideal climate requirement $^{c}$ (Hartley [46]) & Range & & & & \\
\hline $\operatorname{MaxT}\left({ }^{\circ} \mathrm{C}\right)$ & $29-33$ & & & & \\
\hline $\operatorname{MinT}\left({ }^{\circ} \mathrm{C}\right)$ & $22-24$ & & & & \\
\hline
\end{tabular}

TABLE 4: Soil suitability evaluation for oil palm.

\begin{tabular}{|c|c|c|c|c|c|}
\hline Soil limitation (Shamshuddin et al. [47]) & Desirable range & Minor limitation & Serious limitation & Very serious & \\
\hline Soil pH & $>4.0$ & $3.5-4.0$ & $3.0-3.5$ & $<3.0$ & \\
\hline Soil nutrient status ${ }^{\mathrm{a}}$ (Goh [48]) & Very low & Low & Moderate & High & Very high \\
\hline $\mathrm{TN}\left(\mathrm{g} \cdot \mathrm{kg}^{-1}\right)$ & $<0.8$ & $0.8-1.2$ & $1.2-1.5$ & $1.5-2.5$ & $>2.5$ \\
\hline Avail-P (mg.kg $\left.{ }^{-1}\right)$ & $<10$ & $10-25$ & $25-40$ & $40-60$ & $>60$ \\
\hline Exch-K $\left(\mathrm{cmol}_{\mathrm{c}} \cdot \mathrm{kg}^{-1}\right)$ & $<0.08$ & $0.08-0.20$ & $0.20-0.25$ & $0.25-0.30$ & $>0.30$ \\
\hline Exch-Mg $\left(\mathrm{cmol}_{\mathcal{c}} \cdot \mathrm{kg}^{-1}\right)$ & $<0.08$ & $0.08-0.20$ & $0.20-0.25$ & $0.25-0.30$ & $>0.30$ \\
\hline
\end{tabular}

${ }^{\mathrm{a}} \mathrm{TN}=$ total nitrogen; Avail $=$ available; $\mathrm{Exch}=$ exchangeable.

significantly influenced by annual minimum temperature; (ii) clay content $(F=7.29, p<0.01)$ in Subsoil-1 and AcidBC $(F=6.53, p<0.05)$ in Rootzone were significantly influenced by annual water vapor pressure; (iii) Exch-Mg $(F=20.30, p<0.01)$ in Subsoil-2 and Exch-Na $(F=10.05$, $p<0.01)$ and silt content $(F=7.85, p<0.01)$ in Rootzone 
TABle 5: Climate parameters of Central Plain and Southeast Coast.

\begin{tabular}{lcc}
\hline $\begin{array}{l}\text { Climate parameter } \\
\text { (Unit) }\end{array}$ & $\begin{array}{c}\text { Central Plain } \\
\text { Median (range) }\end{array}$ & $\begin{array}{c}\text { Southeast Coast } \\
\text { Median (range) }\end{array}$ \\
\hline PPT $\left(\mathrm{mm} \cdot\right.$ year $\left.^{-1}\right)$ & 1255.50 & 2823.50 \\
& $(1171-1265)$ & $(2167-3245)$ \\
SR $\left(\mathrm{MJ} \cdot \mathrm{m}^{-2}\right)$ & $18.61(16.73-21.48)$ & 18.45 \\
& $(15.86-21.55)$ \\
MeanT $\left({ }^{\circ} \mathrm{C}\right)$ & $27.70(24.90-29.90)$ & 27.44 \\
& & $(25.70-29.00)$ \\
MaxT $\left({ }^{\circ} \mathrm{C}\right)$ & $32.30(29.60-34.20)$ & 30.88 \\
& & $(28.80-32.50)$ \\
MinT $\left({ }^{\circ} \mathrm{C}\right)$ & $23.06(19.90-25.60)$ & 24.00 \\
WVP $(\mathrm{kPa})$ & $2.69(2.05-2.99)$ & $2.86(2.25-3.15)$ \\
WS $\left(\mathrm{m} \cdot \mathrm{s}^{-1}\right)$ & $1.04(0.7-1.4)$ & $2.23(1.5-2.8)$ \\
ETP $\left(\mathrm{mm} \cdot\right.$ day $\left.^{-1}\right)$ & $2.41(2.19-2.84)$ & $2.04(1.77-2.50)$ \\
WD $(\mathrm{mm})$ & 211.21 & $51.22(9.82-89.73)$ \\
& $(195.10-222.51)$ & \\
\hline
\end{tabular}

${ }^{\mathrm{a}} \mathrm{PPT}=$ annual precipitation; $\mathrm{SR}=$ daily solar radiation; $\mathrm{MeanT}=$ annual mean temperature; $\mathrm{MaxT}=$ annual maximum temperature; $\mathrm{MinT}=$ annual minimum temperature; $\mathrm{WVP}=$ annual water vapor pressure; $\mathrm{WS}=$ annual wind speed; ETP = evapotranspiration; $\mathrm{WD}=$ annual water deficit.

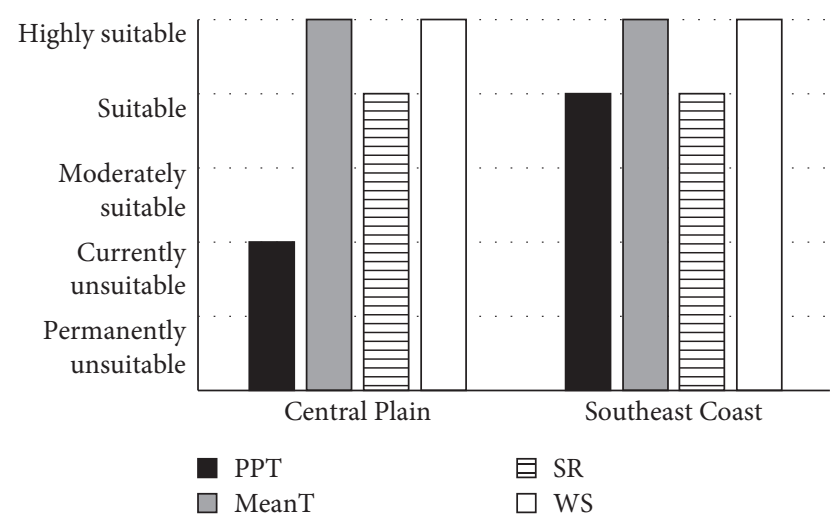

FIgURE 2: Climatic suitability classification ( $\mathrm{PPT}=$ annual precipitation; MeanT = annual mean temperature; $\mathrm{SR}=$ daily solar radiation; $\mathrm{WS}=$ annual wind speed) for oil palm of acid sulfate soils under oil palm planting areas in Central Plain and Southeast Coast, Thailand.

were significantly influenced by daily solar radiation. These indicated that (i) annual minimum temperature accounted for $46 \%$ of clay content in Topsoil, $43 \%$ of AWC in Subsoil-2, and $48 \%$ of clay content in Rootzone; (ii) annual water vapor pressure accounted for $41 \%$ of clay content in Subsoil-1 and $16 \%$ of Acid-BC in Rootzone; (iii) daily solar radiation accounted for $68 \%$ of Exch-Mg in Subsoil-2, and 24\% of Exch-Na and 19\% of silt content in Rootzone.

\section{Discussion}

4.1. Suitability of Climate for Oil Palm. Due to the climatic suitability classification [19], oil palm yields in SC may decrease because the median annual precipitation (Table 5) is greater than $2,500 \mathrm{~mm}$ (Table 3). Too high continuous rains reduce the population of pollinating weevils and subsequently decrease the yields of oil palm because of more precipitation and associated cloudy conditions affecting less radiation can reach the surface [49]. Due to the climatic suitability classification [19] and water deficit suitability classification [25], oil palm plantation in CP should have to compensate precipitation rate and decrease water deficit because the median annual precipitation (Table 5) is lower than $2,000 \mathrm{~mm}$ (Table 3 ) and the median annual water deficit (Table 5) is greater than $150 \mathrm{~mm}$ (Table 3). In Ghana, a previous study by Rhebergen et al. [25] demonstrates that optimal areas (Table 3) for oil palm are in the south of the Western Region and a smaller area west of Koforidua in the Eastern Region which estimated at 580,000 ha or $2 \%$ of the total land areas.

It would be better for the oil palm growers in CP and SC to manage water by using raised beds with irrigation canals to compensate unsuitable precipitation and decrease water deficit in CP. This also include draining water excess before flooding, and controlling water table level carefully to prevent aluminum toxicity [12].

4.2. Suitability of ASSs for Oil Palm. In both $\mathrm{CP}$ and SC, their $\mathrm{pH}_{1: 1}-\mathrm{H}_{2} \mathrm{O}_{2}$ of Topsoil, Subsoil-1, and Subsoil-2 (Table 7) are extremely lower than their $\mathrm{pH}_{1: 1}-\mathrm{H}_{2} \mathrm{O}$ because the lower $\mathrm{pH}_{1: 1}-\mathrm{H}_{2} \mathrm{O}_{2}$ values are caused by oxidation of iron sulfides $[29,50]$ and soil organic matter [51]. Hydrogen peroxide causes not only the oxidation of OM but also the degradation of clay minerals, especially $2: 1$ clay minerals [51]. Therefore, both ASS areas require soil $\mathrm{pH}$ adjustment so as to reduce aluminum toxicity affecting oil palm roots. In addition, considering the median of $\mathrm{pH}_{1: 1}-\mathrm{H}_{2} \mathrm{O}$ in each depth level of CP and SC (Table 7) by soil limitation [48], their soil pH is not in the desirable range except Subsoil-2 and Rootzone of $\mathrm{SC}$ (Figure 4). As a result, the $\mathrm{pH}$ level should be increased to at least $\mathrm{pH} 4.3$ [52] and not to exceed about $\mathrm{pH} 6.0$, with optimal in the range of $\mathrm{pH} 5.0-5.5$ [53] by liming at an appropriate rate and applying organic materials, especially green manure [54]. Liming improve soil conditions and increase oil palm yields in ASS [12], whereas $\mathrm{pH}$ neutralization is faster by sulfate reducing bacteria when adding high-organic carbon in anoxic condition [55, 56]. Besides, high acid buffering capacity (Acid-BC) of both areas (Table 7) was good to maintain their soil $\mathrm{pH}$ when the $\mathrm{pH}$ was raised to the desired level.

The very high Extr-Al (extractable aluminum) contents of both CP and SC are due to their very low soil pH levels (Table 7). At the low $\mathrm{pH}$, toxic aluminum species can form that inhibit the growth of plant roots and subsequently limit ecosystem productivity [57]. Aluminum toxicity is the most important limiting factor for growing plant in ASS [58] and has different effects on the length of primary roots of oil palm in different varieties [59]. Therefore, before applying fertilizer or amendment in ASSs, it is essential to consider (i) the rooting depth of oil palm which can be impeded by dense layers of lateritic or other gravel, solid rock, or unfavorable chemical conditions [17], and (ii) the depth of acidic horizon which oil palm can grow without acidity limitation when the presence of acidic layers occur below $100 \mathrm{~cm}$ from soil surface $[60,61]$. Considering the rooting depth covering the 


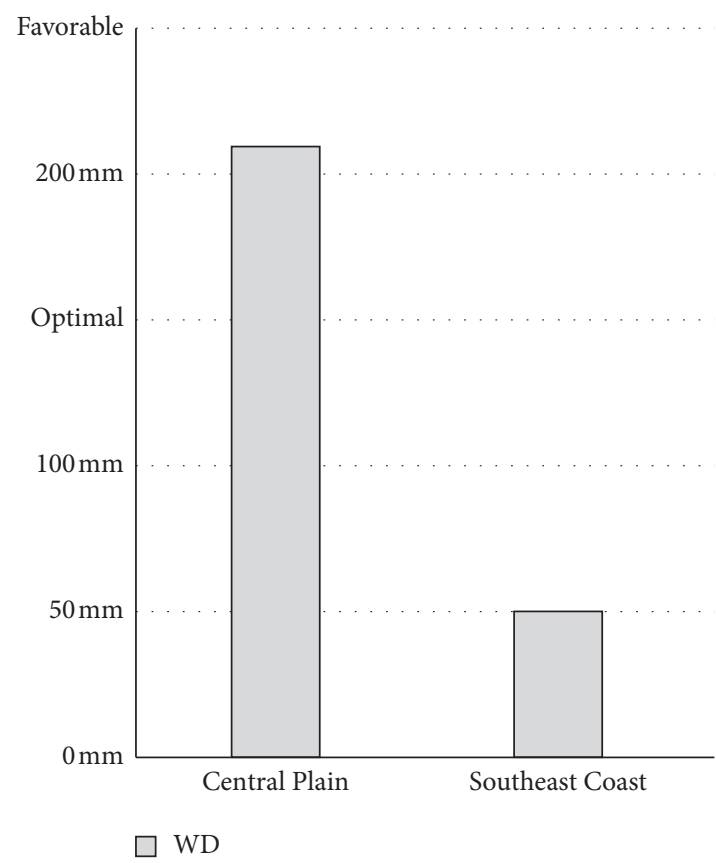

(a)

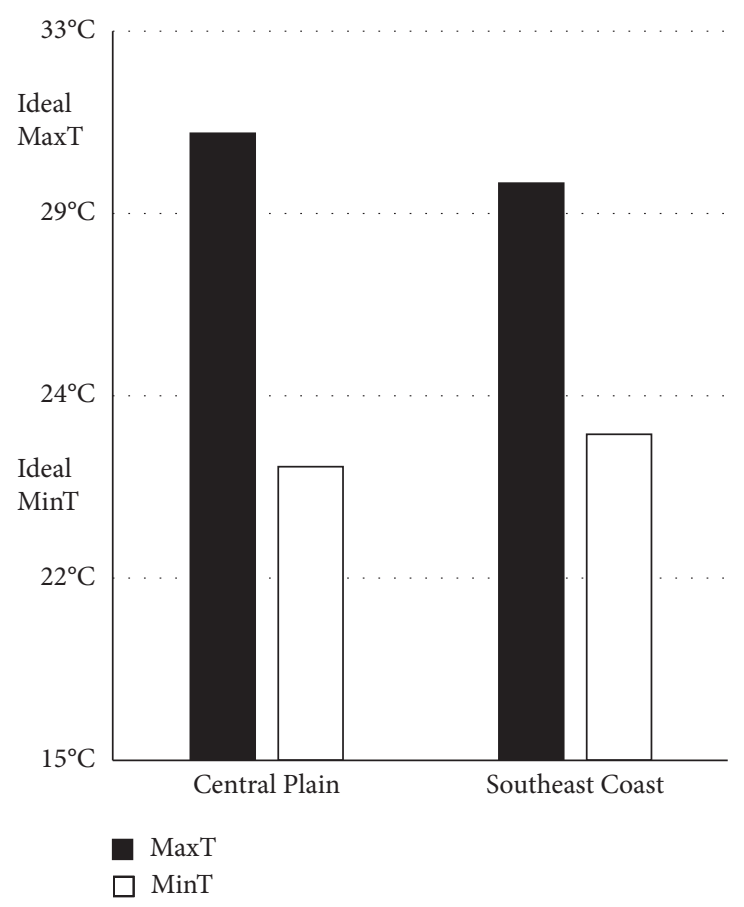

(b)

Figure 3: Water deficit suitability classification ( $\mathrm{WD}=$ annual water deficit) and ideal climate requirement (MaxT $=$ annual maximum temperature; $\mathrm{MinT}=$ annual minimum temperature) for oil palm of acid sulfate soils under oil palm planting areas in Central Plain and Southeast Coast, Thailand.

Table 6: Physical properties of acid sulfate soils under oil palm planting areas in Central Plain and Southeast Coast.

\begin{tabular}{|c|c|c|c|c|c|c|c|c|}
\hline \multirow[b]{2}{*}{$\begin{array}{l}\text { Physical } \\
\text { property }^{\mathrm{a}} \\
\text { (Unit) }\end{array}$} & \multicolumn{4}{|c|}{ Central Plain } & \multicolumn{4}{|c|}{ Southeast Coast } \\
\hline & $\begin{array}{c}\text { Topsoil }^{\mathrm{b}} \\
\text { Median } \\
\text { (range) } \\
n=10\end{array}$ & $\begin{array}{c}\text { Subsoil-1 }^{c} \\
\text { Median } \\
\text { (range) } \\
n=10\end{array}$ & $\begin{array}{c}\text { Subsoil-2 }^{\mathrm{d}} \\
\text { Median } \\
\text { (range) } \\
n=10\end{array}$ & $\begin{array}{c}\text { Rootzone } \\
\text { Median } \\
\text { (range) } \\
n=30\end{array}$ & $\begin{array}{c}\text { Topsoil }^{\mathrm{b}} \\
\text { Median } \\
\text { (range) } \\
n=10\end{array}$ & $\begin{array}{c}\text { Subsoil-1 }^{\mathrm{c}} \\
\text { Median } \\
\text { (range) } \\
n=10\end{array}$ & $\begin{array}{c}\text { Subsoil-2 }^{\mathrm{d}} \\
\text { Median } \\
\text { (range) } \\
n=10\end{array}$ & $\begin{array}{c}\text { Rootzone } \\
\text { Median } \\
\text { (range) } \\
n=30\end{array}$ \\
\hline $\begin{array}{l}\text { Sand } \\
\left(\mathrm{g} \cdot \mathrm{kg}^{-1}\right)\end{array}$ & $35.50(15-70)$ & $25.00(9-125)$ & $\begin{array}{c}36.00 \\
(11-112)\end{array}$ & $33.00(9-125)$ & & $\begin{array}{c}223.50 \\
(80-564)\end{array}$ & & \\
\hline Silt $\left(g \cdot \mathrm{kg}^{-1}\right)$ & $\begin{array}{c}304.50 \\
(269-404)\end{array}$ & $\begin{array}{c}292.50 \\
(265-423)\end{array}$ & $\begin{array}{c}282.50 \\
(253-482)\end{array}$ & $\begin{array}{r}29 \\
(253\end{array}$ & $\begin{array}{r}38 \\
(254\end{array}$ & $\begin{array}{r}37 \\
(251\end{array}$ & $\begin{array}{r}38 \\
(297\end{array}$ & $\begin{array}{r}38 \\
(251\end{array}$ \\
\hline $\begin{array}{l}\text { Clay } \\
\left(\mathrm{g} \cdot \mathrm{kg}^{-1}\right)\end{array}$ & $\begin{array}{c}666.00 \\
(526-704)\end{array}$ & $\begin{array}{c}681.00 \\
(553-712)\end{array}$ & $\begin{array}{c}666.50 \\
(489-708)\end{array}$ & $\begin{array}{c}674.50 \\
(489-712)\end{array}$ & $\begin{array}{c}292.50 \\
(76-531)\end{array}$ & $\begin{array}{c}288.50 \\
(74-574)\end{array}$ & $\begin{array}{c}3560 \\
(79-493)\end{array}$ & $\begin{array}{c}313.50 \\
(74-574)\end{array}$ \\
\hline $\begin{array}{l}\text { AWC } \\
(\mathrm{mm})\end{array}$ & $\begin{array}{c}26.06 \\
(24.32-29.58)\end{array}$ & $\begin{array}{c}25.38 \\
(24.12-30.96)\end{array}$ & $\begin{array}{c}25.26 \\
(23.05-33.32)\end{array}$ & $\begin{array}{c}25.54 \\
(23.05-33.32)\end{array}$ & $\begin{array}{c}25.36 \\
(18.20-31.90)\end{array}$ & $\begin{array}{c}27.33 \\
(17.08-35.34)\end{array}$ & $\begin{array}{c}27.23 \\
(20.23-31.15)\end{array}$ & $\begin{array}{c}26.51 \\
(17.08-35.34)\end{array}$ \\
\hline
\end{tabular}

${ }^{\mathrm{a}} \mathrm{AWC}=$ available water capacity. ${ }^{\mathrm{b}, \mathrm{c}, \mathrm{d}}$ Topsoil $=$ Ap; Subsoil $-1=\mathrm{Ap}-60 \mathrm{~cm}$; Subsoil $-2=60-100 \mathrm{~cm}$; Rootzone $=$ top $100 \mathrm{~cm}$.

total $100 \mathrm{~cm}$ from soil surface with the interpretation of soil nutrient status for fertilizer recommendations [48] (Figure 5). The growers in CP should maintain $\mathrm{N}$ and $\mathrm{P}$ fertilizer rate, and not input $\mathrm{K}$ and $\mathrm{Mg}$ fertilizer except to correct nutrient imbalance because the Rootzone had moderate TN, low Avail-P, and very high Exch-K and Exch-Mg. The input $\mathrm{K}$ fertilizer rate is different from the recent study by Palykaew et al. [62] that the rate should be sufficient due to the low to very high of Avail-K (available potassium) which tends to increase with depth levels, whereas the growers in SC should decrease $\mathrm{N}$ and $\mathrm{K}$ fertilizer rates, maintain $\mathrm{P}$ fertilizer rate, and not input $\mathrm{Mg}$ fertilizer except to correct nutrient imbalance because the Rootzone had high TN and Exch-K, very low Avail-P, and very high Exch-Mg. The P fertilizer rate of both ASSs areas should not be increased because the reactions that fix $\mathrm{P}$ in relatively unavailable forms are related to soil $\mathrm{pH}[63]$.

4.3. Influence of Climate on Physicochemical Properties of ASSs. Physical properties of soils are grossly static in their response to change in climatic conditions, whereas chemical properties are more dynamic to changes in climatic conditions $[64,65]$. The findings of this study indicated that (Table 8) (i) in CP, daily solar radiation was the most significant climate parameter that influenced ASS properties in all depth levels; it influenced clay content in topsoil, CEC in the range of topsoil- $60 \mathrm{~cm}$, soil $\mathrm{pH}$ by water in the range of 
TABLe 7: Chemical properties of acid sulfate soils under oil palm planting areas in Central Plain and Southeast Coast.

\begin{tabular}{|c|c|c|c|c|c|c|c|c|}
\hline \multirow[b]{2}{*}{$\begin{array}{l}\text { Chemical property } \\
\text { (unit) }\end{array}$} & \multicolumn{4}{|c|}{ Central Plain } & \multicolumn{4}{|c|}{ Southeast Coast } \\
\hline & $\begin{array}{c}\text { Topsoil }^{\mathrm{b}} \\
\text { Median } \\
\text { (range) } \\
n=10\end{array}$ & $\begin{array}{c}\text { Subsoil-1 }^{\mathrm{c}} \\
\text { Median } \\
\text { (range) } \\
n=10\end{array}$ & $\begin{array}{c}\text { Subsoil-2 }^{\mathrm{d}} \\
\text { Median } \\
\text { (range) } \\
n=10\end{array}$ & $\begin{array}{c}\text { Rootzone } \\
\text { Median } \\
\text { (range) } \\
n=30\end{array}$ & $\begin{array}{c}\text { Topsoil }^{\mathrm{b}} \\
\text { Median } \\
\text { (range) } \\
n=10\end{array}$ & $\begin{array}{c}\text { Subsoil-1 }^{\mathrm{c}} \\
\text { Median } \\
\text { (range) } \\
n=10\end{array}$ & $\begin{array}{c}\text { Subsoil-2 }^{\mathrm{d}} \\
\text { Median } \\
\text { (range) } \\
n=10\end{array}$ & $\begin{array}{c}\text { Rootzone } \\
\text { Median } \\
\text { (range) } \\
n=30\end{array}$ \\
\hline $\mathrm{pH}_{1: 1}-\mathrm{H}_{2} \mathrm{O}$ & $\begin{array}{c}3.65 \\
(3.3-6.9)\end{array}$ & $3.45(3.3-5.5)$ & $3.50(3.3-5)$ & $\begin{array}{c}3.50 \\
(3.3-6.9)\end{array}$ & $\begin{array}{c}3.80 \\
(2.8-4.9)\end{array}$ & $3.90(2.8-5)$ & $\begin{array}{c}4.80 \\
(3.3-6.6)\end{array}$ & $4.15(2.8-6.6)$ \\
\hline $\mathrm{pH}_{1: 1}-\mathrm{H}_{2} \mathrm{O}_{2}$ & $\begin{array}{c}2.35 \\
(1.8-5.8)\end{array}$ & $2.30(1.9-3)$ & $2.30(1.9-2.6)$ & $\begin{array}{c}2.30 \\
(1.8-5.8)\end{array}$ & $\begin{array}{c}2.60 \\
(2.2-3.2)\end{array}$ & $2.55(2.2-3.7)$ & $\begin{array}{c}2.45 \\
(2.1-5.7)\end{array}$ & $2.50(2.1-5.7)$ \\
\hline OC $\left(\mathrm{g} \cdot \mathrm{kg}^{-1}\right)$ & $\begin{array}{c}19.10 \\
(11.4-51.7)\end{array}$ & $\begin{array}{c}16.75 \\
(8.9-22.7)\end{array}$ & $\begin{array}{c}9.20 \\
(5.6-23.2)\end{array}$ & $\begin{array}{r}16 \\
(5.6-\end{array}$ & $\begin{array}{c}32.90 \\
(5.3-102)\end{array}$ & $\begin{array}{c}18.95 \\
(2.9-140)\end{array}$ & $\begin{array}{c}25.45 \\
(1.9-112)\end{array}$ & $\begin{array}{c}25.45 \\
(1.9-140)\end{array}$ \\
\hline $\mathrm{TN}\left(\mathrm{g} \cdot \mathrm{kg}^{-1}\right)$ & $\begin{array}{c}1.68 \\
(0.84-3.22)\end{array}$ & $\begin{array}{c}1.44 \\
(0.7-2.87)\end{array}$ & $\begin{array}{c}0.81 \\
(0.42-1.89)\end{array}$ & $\begin{array}{c}1.40 \\
(0.42-3.22)\end{array}$ & $\begin{array}{c}1.925 \\
(1.33-4.54)\end{array}$ & $\begin{array}{c}1.955 \\
(1.05-3.22)\end{array}$ & $\begin{array}{c}2.06 \\
(1.19-2.79)\end{array}$ & $\begin{array}{c}1.99 \\
(1.05-4.54)\end{array}$ \\
\hline Avail-P (mg.kg $\left.{ }^{-1}\right)$ & $\begin{array}{c}46.50 \\
(6-1045)\end{array}$ & $\begin{array}{c}10.00 \\
(0.9-203)\end{array}$ & $\begin{array}{c}11.30 \\
(0.4-19)\end{array}$ & $\begin{array}{r}13 \\
(0.4-\end{array}$ & $\begin{array}{c}6.10 \\
(1.1-42.2)\end{array}$ & $\begin{array}{c}4.40 \\
(0.9-127)\end{array}$ & $\begin{array}{c}14.75 \\
(2.3-126)\end{array}$ & $\begin{array}{c}6.20 \\
(0.9-127)\end{array}$ \\
\hline Avail-K (mg.kg $\left.{ }^{-1}\right)$ & $\begin{array}{c}128.00 \\
(64-907)\end{array}$ & $\begin{array}{c}99.00 \\
(55-269)\end{array}$ & $\begin{array}{c}96.50 \\
(69-173)\end{array}$ & $\begin{array}{r}115 \\
(55-\end{array}$ & $\begin{array}{c}54.50 \\
(8-168)\end{array}$ & $53.00(3-313)$ & $\begin{array}{c}181.50 \\
(4-338)\end{array}$ & $74.00(3-338)$ \\
\hline $\begin{array}{l}\text { Extr-SO }{ }_{4}^{2-} \\
\left(\mathrm{mg} \cdot \mathrm{kg}^{-1}\right)\end{array}$ & $\begin{array}{c}258.50 \\
(32-441)\end{array}$ & $\begin{array}{c}385.00 \\
(199-933)\end{array}$ & $\begin{array}{c}484.00 \\
(313-1042)\end{array}$ & $\begin{array}{c}380.50 \\
(32-1042)\end{array}$ & $\begin{array}{c}349.00 \\
(33-5890)\end{array}$ & $\begin{array}{c}574 \\
(12-\end{array}$ & $\begin{array}{c}525.00 \\
(3-4290)\end{array}$ & $\begin{array}{c}525.00 \\
(3-6583)\end{array}$ \\
\hline $\mathrm{EA}\left(\mathrm{cmol}_{\mathrm{c}}\right.$ & $\begin{array}{c}35.00 \\
(6-58)\end{array}$ & $40.50(23-56)$ & $36.50(23-51)$ & $\begin{array}{c}37.00 \\
(6-58)\end{array}$ & $28.50(8-58)$ & 17.00 & $\begin{array}{l}33.50 \\
(7-45)\end{array}$ & $28.50(4-109)$ \\
\hline $\mathrm{EC}\left(\mathrm{dS} \cdot \mathrm{m}^{-1}\right)$ & $\begin{array}{c}0.14 \\
(0.07-0.24)\end{array}$ & $\begin{array}{c}0.20 \\
(0.13-0.81)\end{array}$ & $\begin{array}{c}0.32 \\
(0.19-0.8)\end{array}$ & $\begin{array}{c}0.22 \\
(0.07-0.81)\end{array}$ & $\begin{array}{c}0.59 \\
(0.04-5.27)\end{array}$ & $\begin{array}{c}0.62 \\
(0.03-3.63)\end{array}$ & $\begin{array}{c}1.26 \\
(0.13-5.25)\end{array}$ & $\begin{array}{c}0.76 \\
(0.03-5.27)\end{array}$ \\
\hline $\begin{array}{l}\text { Exch-K } \\
\left(\mathrm{cmol}_{\mathrm{c}} \cdot \mathrm{kg}^{-1}\right)\end{array}$ & $\begin{array}{c}0.50 \\
(0.17-2.68)\end{array}$ & $\begin{array}{c}0.29 \\
(0.19-1.78)\end{array}$ & $\begin{array}{c}0.29 \\
(0.23-0.62)\end{array}$ & $\begin{array}{c}0.35 \\
(0.17-2.68)\end{array}$ & $\begin{array}{c}0.19 \\
(0.06-0.67)\end{array}$ & $\begin{array}{c}0.22 \\
(0.04-1.33)\end{array}$ & $\begin{array}{c}0.66 \\
(0.05-1.46)\end{array}$ & $\begin{array}{c}0.28 \\
(0.04-1.46)\end{array}$ \\
\hline $\begin{array}{l}\text { Exch-Ca } \\
\left(\mathrm{cmol}_{\mathrm{c}} \cdot \mathrm{kg}^{-1}\right)\end{array}$ & $\begin{array}{c}5.21 \\
(0.4-25.5)\end{array}$ & $\begin{array}{c}2.57 \\
(0.97-13.2)\end{array}$ & $\begin{array}{c}2.28 \\
(0.78-6.87)\end{array}$ & $\begin{array}{c}2.85 \\
(0.4-25.5)\end{array}$ & $\begin{array}{c}1.71 \\
(0.59-15.6)\end{array}$ & $\begin{array}{c}2.43 \\
(0.68-4.23)\end{array}$ & $\begin{array}{c}3.01 \\
(0.81-14.5)\end{array}$ & $\begin{array}{c}2.40 \\
(0.59-15.6)\end{array}$ \\
\hline $\begin{array}{l}\text { Exch-Mg } \\
\left(\mathrm{cmol}_{\mathrm{c}} \mathrm{kg}^{-1}\right)\end{array}$ & $\begin{array}{c}1.86 \\
(0.2-5.41)\end{array}$ & $\begin{array}{c}1.35 \\
(0.3-3.03)\end{array}$ & $\begin{array}{c}1.11 \\
(0.48-5.24)\end{array}$ & $\begin{array}{c}1.30 \\
(0.2-5.41)\end{array}$ & $\begin{array}{c}2.36 \\
(0.18-13.1)\end{array}$ & $\begin{array}{c}3.97 \\
(0.1-10.3)\end{array}$ & $\begin{array}{c}6.01 \\
(0.22-30.1)\end{array}$ & $\begin{array}{c}3.90 \\
(0.1-30.1)\end{array}$ \\
\hline $\begin{array}{l}\text { Exch-Na } \\
\left(\mathrm{cmol}_{\mathrm{c}} \cdot \mathrm{kg}^{-1}\right)\end{array}$ & $\begin{array}{c}0.20 \\
(0.05-0.57)\end{array}$ & $\begin{array}{c}0.34 \\
(0.18-1.24)\end{array}$ & $\begin{array}{c}0.44 \\
(0.1-1.49)\end{array}$ & $\begin{array}{c}0.33 \\
(0.05-1.49)\end{array}$ & $\begin{array}{c}0.34 \\
(0.09-6.09)\end{array}$ & $\begin{array}{c}0.87 \\
(0.05-7.96)\end{array}$ & $\begin{array}{c}1.47 \\
(0.13-16.7)\end{array}$ & $\begin{array}{c}1.00 \\
(0.05-16.7)\end{array}$ \\
\hline $\mathrm{CEC}\left(\mathrm{cmol}_{\mathrm{c}} \cdot \mathrm{kg}^{-1}\right)$ & $\begin{array}{c}30.50 \\
(27-39)\end{array}$ & $29.00(21-42)$ & $26.50(18-33)$ & $\begin{array}{c}28.00 \\
(18-42)\end{array}$ & $\begin{array}{c}18.55 \\
(4.75-31.2)\end{array}$ & $\begin{array}{c}15.45 \\
(1.5-34.4)\end{array}$ & $\begin{array}{c}17.30 \\
(1.5-26.6)\end{array}$ & $\begin{array}{c}16.55 \\
(1.5-34.4)\end{array}$ \\
\hline BSP (\%) & $\begin{array}{c}16.05 \\
(1.9-85)\end{array}$ & $\begin{array}{c}11.05 \\
(3.6-32.2)\end{array}$ & $\begin{array}{c}12.35 \\
(5.6-27.7)\end{array}$ & $\begin{array}{c}11.60 \\
(1.9-85)\end{array}$ & $\begin{array}{c}22.40 \\
(3.21-76.9)\end{array}$ & $\begin{array}{c}28.05 \\
(2.06-78.8)\end{array}$ & $\begin{array}{c}34.30 \\
(3.71-81.6)\end{array}$ & $\begin{array}{c}31.65 \\
(2.06-81.6)\end{array}$ \\
\hline Extr-Al $\left(\mathrm{mg} \cdot \mathrm{kg}^{-1}\right)$ & $\begin{array}{l}1037.50 \\
(2-1435)\end{array}$ & $\begin{array}{c}1161.00 \\
(309-1498)\end{array}$ & $\begin{array}{c}1316.50 \\
(510-1593)\end{array}$ & $\begin{array}{l}1133.00 \\
(2-1593)\end{array}$ & $\begin{array}{c}169.00 \\
(15-2882)\end{array}$ & $\begin{array}{c}280.00 \\
(0.53-2367)\end{array}$ & $\begin{array}{c}111.00 \\
(3.8-815)\end{array}$ & $\begin{array}{c}160.00 \\
(0.53-2882)\end{array}$ \\
\hline $\begin{array}{l}\text { Acid-BC (mmol } \\
\left.\mathrm{H}^{+} \cdot \mathrm{kg}^{-1}\right)\end{array}$ & $\begin{array}{c}82.00 \\
(16-2361)\end{array}$ & $\begin{array}{c}85.00 \\
(30-2992)\end{array}$ & $\begin{array}{c}81.50 \\
(53-125)\end{array}$ & $\begin{array}{c}82.00 \\
(16-2992)\end{array}$ & $\begin{array}{c}140.50 \\
(57-321)\end{array}$ & $\begin{array}{c}133.00 \\
(39-332)\end{array}$ & $\begin{array}{l}129.50 \\
(12-176)\end{array}$ & $\begin{array}{c}130.50 \\
(12-332)\end{array}$ \\
\hline $\begin{array}{l}\text { Base-BC (mmol } \\
\left.\mathrm{OH}^{-} \cdot \mathrm{kg}^{-1}\right)\end{array}$ & $\begin{array}{l}39.00 \\
(6-86)\end{array}$ & $23.00(5-64)$ & $19.00(6-56)$ & $\begin{array}{l}27.50 \\
(5-86)\end{array}$ & $\begin{array}{c}58.00 \\
(28-153)\end{array}$ & $\begin{array}{c}59.50 \\
(13-610)\end{array}$ & $\begin{array}{c}364.00 \\
(10-878)\end{array}$ & $\begin{array}{c}80.00 \\
(10-878)\end{array}$ \\
\hline
\end{tabular}

${ }^{\mathrm{a}} \mathrm{OC}=$ organic carbon; $\mathrm{TN}=$ total nitrogen; Avail = available; Extr = extractable; EA = extractable acidity; EC = electrical conductivity; Exch = exchangeable; $\mathrm{CEC}=$ cation exchange capacity; $\mathrm{BSP}=$ base saturation percentage; $\mathrm{BC}=$ buffering capacity. ${ }^{\mathrm{b}, \mathrm{c}, \mathrm{d}}$ Topsoil = Ap; Subsoil-1 $=\mathrm{Ap}-60 \mathrm{~cm} ; \mathrm{Subsoil}-2=60-100 \mathrm{~cm}$; Rootzone $=$ top $100 \mathrm{~cm}$.

$60-100 \mathrm{~cm}$, and silt content covering the overall $100 \mathrm{~cm}$ from soil surface; (ii) in SC, annual minimum temperature was one of the most significant climate parameters that influenced ASS properties in almost all of the depth levels. It influenced clay content in topsoil, AWC in the range of $60-100 \mathrm{~cm}$, and clay content covering the overall $100 \mathrm{~cm}$ from soil surface, whereas daily solar radiation influenced Exch-Mg in the range of $60-100 \mathrm{~cm}$, Exch-Na and silt content covering the total $100 \mathrm{~cm}$ from soil surface. Therefore, it is important to emphasize the daily solar radiation in both areas because it was the major influential one of climatic parameters on soil properties due to the transport of heat in soils which is mostly governed by solar radiation during day time and the soil radiation to atmosphere during night time [66]. In addition, annual minimum temperature was the major influential of climatic parameters on soil properties in SC. These results indicated influence of soil temperature from daily solar radiation and annual minimum temperature on ASS properties due to their effect on the rates of physical, chemical, and biological reactions and process in the soil $[67,68]$.

On the other hand, particle size distribution was the most significant ASS property in both areas which was influenced by climatic parameters due to their clay and silt fractions (Table 8). Clay fraction is the most active and important fraction of soils because it retains moisture and nutrients, including its minerals that determine the potential fertility of soils via their CEC [69], whereas the silt fraction has not only a larger surface area but also a faster weathering rate and release of soluble nutrients for plant, compared with the sand fraction [70].

Climate can have an important influence on soil properties and their dynamics, especially precipitation and 
TABLE 8: Results of stepwise multiple regression analysis on climate and soil variables.

\begin{tabular}{|c|c|c|c|c|}
\hline Climate parameter $^{\mathrm{a}}$ & Soil property ${ }^{\mathrm{b}}$ & Adjusted $R^{2}$ & F value & Regression equation $^{\mathrm{ab}}$ \\
\hline $\begin{array}{l}\text { Topsoil of Central Plain } \\
\text { SR } \\
\text { Subsoil-1 of Central Plain }\end{array}$ & Cla & 0.332 & $5.464^{*}$ & $\mathrm{Cla}=1208.807 \mathrm{SR}-21836.138$ \\
\hline SR & CEC & 0.488 & $9.584^{*}$ & $\mathrm{CEC}=160.904 \mathrm{SR}-2964.165$ \\
\hline $\begin{array}{l}\text { Subsoil-2 of Central Plain } \\
\text { SR }\end{array}$ & $\mathrm{pH}_{1: 1}-\mathrm{H}_{2} \mathrm{O}$ & 0.567 & $12.788^{* *}$ & $\mathrm{pH}-\mathrm{H}_{2} \mathrm{O}=-12.160 \mathrm{SR}+229.890$ \\
\hline $\begin{array}{l}\text { Rootzone of Central Plain } \\
\text { SR } \\
\text { WD }\end{array}$ & $\begin{array}{c}\text { Sil } \\
\text { Acid-BC }\end{array}$ & $\begin{array}{l}0.513 \\
0.114 \\
\end{array}$ & $\begin{array}{c}31.591^{* * *} \\
4.719^{*} \\
\end{array}$ & $\begin{array}{c}\text { Sil }=-1246.185 S R+23500.175 \\
\text { Acid-BC }=33.102 W D-6697.325\end{array}$ \\
\hline $\begin{array}{l}\text { Topsoil of Southeast Coast } \\
\text { MinT }\end{array}$ & Cla & 0.456 & $8.552^{*}$ & $\mathrm{Cla}=653.538 \mathrm{MinT}-15356.974$ \\
\hline $\begin{array}{l}\text { Subsoil-1 of Southeast Coast } \\
\text { WVP }\end{array}$ & Cla & 0.412 & $7.294^{* *}$ & $\mathrm{Cla}=12485.157 \mathrm{WVP}-35328.988$ \\
\hline $\begin{array}{l}\text { Subsoil-2 of Southeast Coast } \\
\text { MinT } \\
\text { SR }\end{array}$ & $\begin{array}{c}\text { AWC } \\
\text { Exch-Mg }\end{array}$ & $\begin{array}{l}0.429 \\
0.682 \\
\end{array}$ & $\begin{array}{c}7.752^{*} \\
20.297^{* *} \\
\end{array}$ & $\begin{array}{l}\mathrm{AWC}=20.222 \mathrm{MinT}-458.125 \\
\text { Exch-Mg }=-51.119 \mathrm{SR}+949.075\end{array}$ \\
\hline $\begin{array}{l}\text { Rootzone of Southeast Coast } \\
\text { MinT } \\
\text { SR } \\
\text { SR } \\
\text { WVP }\end{array}$ & $\begin{array}{c}\text { Cla } \\
\text { Exch-Na } \\
\text { Sil } \\
\text { Acid-BC }\end{array}$ & $\begin{array}{l}0.484 \\
0.238 \\
0.191 \\
0.160\end{array}$ & $\begin{array}{c}28.231^{* * *} \\
10.045^{* *} \\
7.848^{* *} \\
6.525^{*}\end{array}$ & $\begin{array}{c}\mathrm{Cla}=686.109 \mathrm{MinT}-16119.176 \\
\text { Exch-Na }=-13.199 \mathrm{SR}+245.424 \\
\mathrm{Sil}=-240.493 \mathrm{SR}+4811.905 \\
\text { Acid-BC }=4053.929 \mathrm{WVP}-11432.263\end{array}$ \\
\hline
\end{tabular}

${ }^{\mathrm{a}}$ Topsoil = Ap; Subsoil-1 = Ap-60 cm; Subsoil $-2=60-100 \mathrm{~cm}$; Rootzone $=$ top $100 \mathrm{~cm}$; SR = daily solar radiation; $\mathrm{WD}=$ annual water deficit; MinT $=$ annual minimum temperature; $\mathrm{WVP}=$ annual water vapor pressure. ${ }^{\mathrm{b}} \mathrm{Acid}-\mathrm{BC}=$ acid buffering capacity; Sil $=$ silt content; Cla $=$ clay content; Exch$\mathrm{Na}=$ exchangeable sodium; $\mathrm{CEC}=$ cation exchange capacity; $\mathrm{pH}_{1: 1}-\mathrm{H}_{2} \mathrm{O}=$ soil $\mathrm{pH}$ by water; $\mathrm{AWC}=$ available water capacity; Exch- $\mathrm{Mg}=$ extractable magnesium. ${ }^{*, * * * * *}$ Significance at $5 \%, 1 \%$, and $0.1 \%$ alpha levels, respectively.

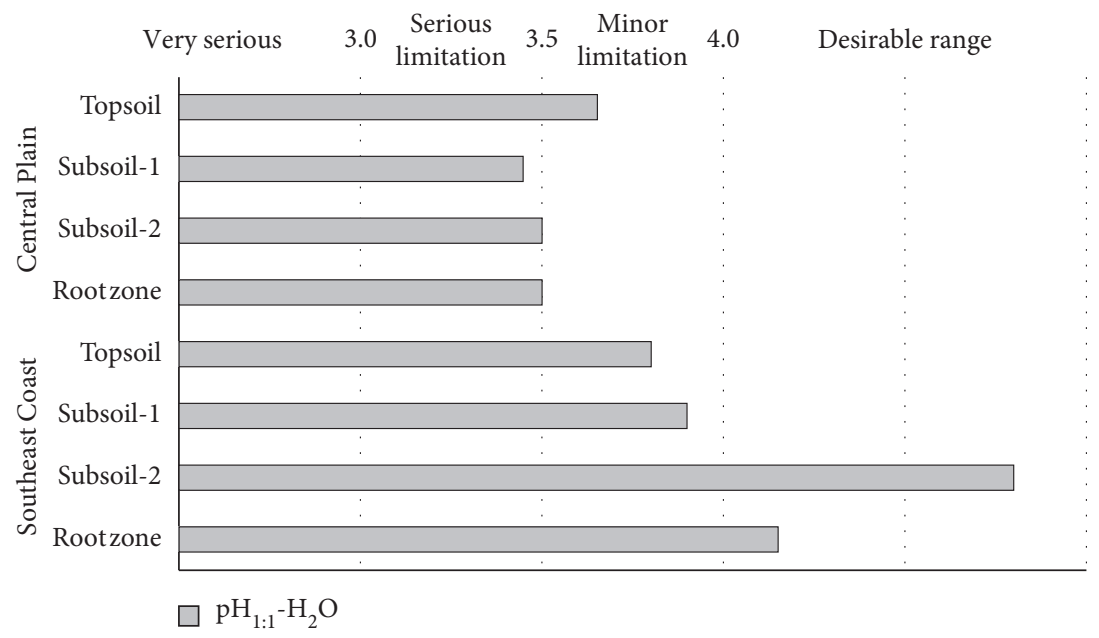

Figure 4: The soil limitation for oil palm of acid sulfate soils under oil palm planting areas in Central Plain and Southeast Coast, Thailand.

temperature [71]. Many significant correlations reported about the increasing precipitation and/or decreasing temperature with increment in soil organic carbon [72-75]. In addition, contents of $\mathrm{Mg}, \mathrm{Fe}, \mathrm{Ca}$, and $\mathrm{Al}$ decreased with increasing precipitation while contents of $\mathrm{Na}$ and $\mathrm{K}$ increased with increasing temperature [76]. Our study indicated the importance of soil temperature on changing of ASS properties affecting directly or indirectly effective oil palm plantation. For example, magnesium (Table 8), which is influenced by daily solar radiation, is one of the key nutrients affecting oil palm growth and yield [22]. Soil temperature also affects the production of $\mathrm{CO}_{2}$ in soils which influence the rates of microbial activity [77] and roots respiration [78].

\section{Conclusion}

The overall results of Thai ASSs under oil palm planting areas in CP and SC indicated that daily solar radiation not only was the most significant climate parameter but it also influenced silt content (mainly quartz) covering the overall $100 \mathrm{~cm}$ from soil surface of both ASS areas. Particle size distribution was the most significant ASS property in both areas that was influenced by climatic parameters. These 


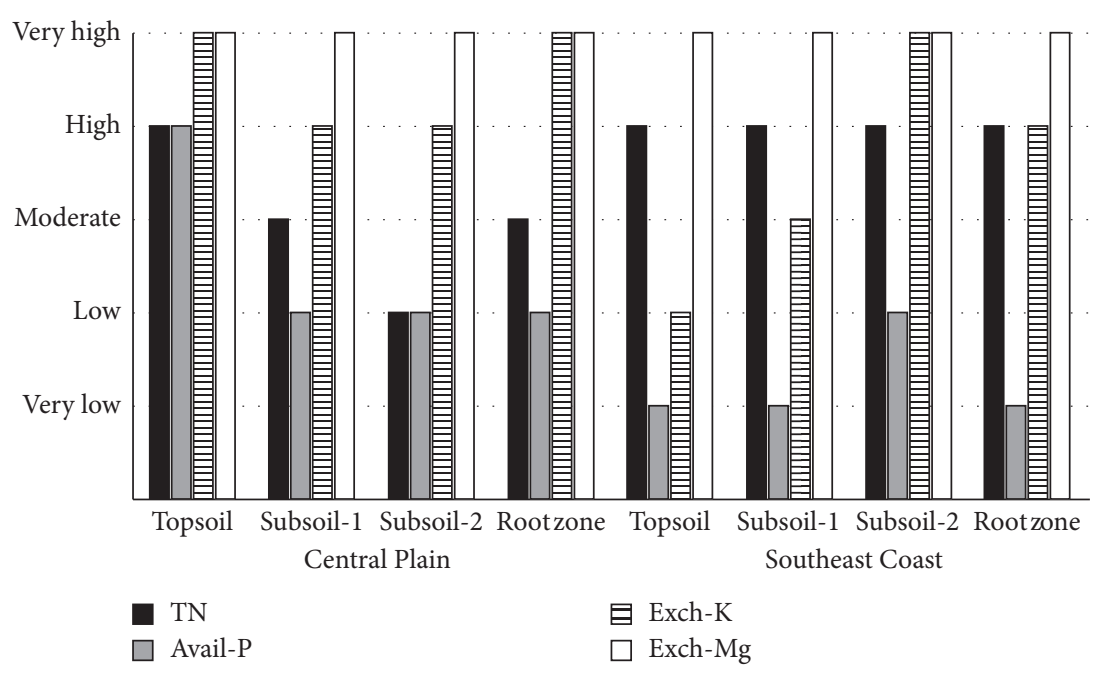

FIGURE 5: The soil nutrient status for fertilizer recommendations $(\mathrm{TN}=$ total nitrogen; Avail = available; Exch = exchangeable $)$ of acid sulfate soils under oil palm planting areas in Central Plain and Southeast Coast, Thailand.

results indicated the importance of soil temperature on changing ASS properties affecting directly or indirectly on effective oil palm plantation and suggested that sustainable oil palm plantation in ASS under tropical savanna and tropical monsoon climates should include management of water use by devising raised beds with irrigation canals to compensate precipitation, decrease water deficit, draining water excess before flooding, and controlling water table level carefully to prevent aluminum toxicity. Besides, the rooting depth of oil palm and depth of acidic horizon should be considered before applying fertilizer or amendment. There is a need to improve soil conditions and increase yields by liming along with integrated organic material management to raise the soil $\mathrm{pH}$ to at least 4.3 but not exceed 6 .

\section{Data Availability}

All data generated or analyzed during this study are included within the article as the supplementary information files.

\section{Conflicts of Interest}

The authors declare that there are no conflicts of interest.

\section{Acknowledgments}

The authors would like to thank Chaipat Khongkeaw for his assistance on soil analyses and Yutika Chanlaksana for her advice on chemical analyses. Funding for this research project was provided by the Thailand Research Fund (TRF).

\section{Supplementary Materials}

Table S1: results of principal component analysis with concept of component defining variable on climate parameters ( $n=10$ and 30$)$. Table S2: results of principal component analysis with concept of component defining variable on soil properties of topsoil $(n=10)$. Table S3: results of principal component analysis with concept of component defining variable on soil properties of subsoil-1 $(n=10)$. Table S4: results of principal component analysis with concept of component defining variable on soil properties of subsoil-2 $(n=10)$. Table S5: results of principal component analysis with concept of component defining variable on soil properties of rootzone $(n=30)$. (Supplementary Materials)

\section{References}

[1] O. Pye, "Introduction," in The Palm Oil Controversy in Southeast Asia: A Transnational Perspective, O. Pye and J. Bhattacharya, Eds., pp. 1-18, ISEAS Publishing, Singapore, 2013.

[2] J. C. Kurnia, S. V. Jangam, S. Akhtar, A. P. Sasmito, and A. S. Mujumdar, "Advances in biofuel production from oil palm and palm oil processing wastes: a review," Biofuel Research Journal, vol. 3, no. 1, pp. 332-346, 2016.

[3] I. Mukherjee and B. K. Sovacool, "Palm oil-based biofuels and sustainability in southeast Asia: a review of Indonesia, Malaysia, and Thailand," Renewable and Sustainable Energy Reviews, vol. 37, pp. 1-12, 2014.

[4] AGRIMAN, "Oil palm plantation technology in abandoned tangerine orchard of Rangsit," December 2018, http://www. agriman.doae.go.th/home/Research/Oilpalm56/2_Binder1. pdf.

[5] S. Chutiratanapan and S. Nielapan, Utilization of Geographic Information System and Plant Modeling to Study the Potential Area Out of Suitable Land to Extend Oil Palm Plantation Area for Energy Substitution, Land Development Department, Office of Agricultural Economics, Bangkok, Thailand, 2007.

[6] D. Dent, Acid Sulphate Soils: A Baseline For Research and Development, No. 39, International Institute for Land Reclamation and Improvement/ILRI, Wageningen, Netherlands, 1986.

[7] R. Langenhoff, Distribution, Mapping, Classification and Use of Acid Sulphate Soils in the Tropics: A Literature Study, Soil Survey Institute, Wageningen, Netherlands, 1986.

[8] N. van Breemen and L. J. Pons, "Acid sulfate soils and rice," in Soils and Rice, pp. 739-761, International Rice Research Institute, Los Baños, Philippines, 1978. 
[9] I. Kheoruenromn, Acid Sulfate Soil in Thailand, Text and Journal Publication Ltd, Bangkok, Thailand, 2007.

[10] P. Y. Toh and Y. C. Poon, "Effect of water management on field performance of oil palms on acid sulphate soils in Peninsular Malaysia," in Proceedings of the Bangkok Symposium on Acid Sulphate Soils, vol. 31, pp. 260-271, ILRI Publication, Wageningen, Netherlands, 1982.

[11] C. Bloomfield, J. K. Coulter, and R. Kanaris-Sotiriou, "Oil palms on acid sulphate soils in Malaya," Tropical Agriculture (Trinidad), vol. 45, pp. 289-300, 1968.

[12] J. Shamshuddin, A. Elisa Azura, M. A. R. S. Shazana, C. I. Fauziah, Q. A. Panhwar, and U. A. Naher, "Chapter three-properties and management of acid sulfate soils in Southeast Asia for sustainable cultivation of rice, oil palm, and cocoa," in Advances in Agronomy, D. L. Sparks, Ed., vol. 124, pp. 91-142, Academic Press, Cambridge, MA, USA, 2014.

[13] DEDE, Alternative Energy Development Plan: AEDP2015, Department of Alternative Energy Development and Efficiency, Ministry of Energy, Bangkok, Thailand, 2015.

[14] OAE, "Oil palm: harvested area, production, and yield per rai, 2014-2016," December 2016, http://oldweb.oae.go.th/ download/prcai/farmcrop/palm.pdf.

[15] T. Silalertruksa, S. H. Gheewala, P. Pongpat et al., "Environmental sustainability of oil palm cultivation in different regions of Thailand: greenhouse gases and water use impact," Journal of Cleaner Production, vol. 167, pp. 1009-1019, 2017.

[16] K. Suresh, R. K. Mathur, and S. K. Behera, "Oil palm," in Abiotic Stress Physiology of Horticultural Crops, N. K. S. Rao, K. S. Shivashankara, and R. H. Laxman, Eds., pp. 333-342, Springer, New Delhi, India, 2016.

[17] R. H. V. Corley and P. B. H. Tinker, The Oil Palm, WileyBlackwell, Oxford, UK, 5th edition, 2015.

[18] F. Nkodo, N. R. Pentane, and F. O. Tabi, "Most responsive periods to climatic factor variations before harvest in oil palm (Elaeis guineensis Jacq.) and their quantitative relationships with yields in the coastal zone of Cameroon," Agriculture and Biology Journal of North America, vol. 7, no. 2, pp. 70-85, 2016.

[19] K. J. Goh, "Climatic requirements of the oil palm for high yields," in Managing Oil Palm for High Yields: Agronomic Principles, K. J. Goh, Ed., pp. 1-17, Malaysian Society of Soil Science and Param Agricultural Surveys, Kuala Lumpur, Malaysia, 2000.

[20] K. H. Lim, K. J. Goh, K. K. Kee, and I. E. Henson, "Climatic requirements of oil palm," in Agronomic Principles and Practices of Oil Palm Cultivation, K. J. Goh, S. B. Chiu, and S. Paramananthan, Eds., pp. 1-46, Agricultural Crop Trust (ACT), Selangor, Malaysia, 2011.

[21] C. Surre, "Les besoins en eau du palmier à huile : calcul du bilan de l'eau et ses applications pratiques," Oléagineux, vol. 23, no. 3, pp. 165-167, 1968.

[22] L. S. Woittiez, M. T. van Wijk, M. Slingerland, M. van Noordwijk, and K. E. Giller, "Yield gaps in oil palm: a quantitative review of contributing factors," European Journal of Agronomy, vol. 83, pp. 57-77, 2017.

[23] J. Olivin, "Étude pour la localisation d'un bloc industriel de palmiers à huile," Oléagineux, vol. 23, pp. 499-504, 1968.

[24] D. Cros, A. Flori, L. Nodichao, A. Omoré, and B. Nouy, "Differential response to water balance and bunch load generates diversity of bunch production profiles among oil palm crosses (elaeis guineensis)," Tropical Plant Biology, vol. 6, no. 1, pp. 26-36, 2013.

[25] T. Rhebergen, T. Fairhurst, S. Zingore, M. Fisher, T. Oberthür, and A. Whitbread, "Climate, soil and land-use based land suitability evaluation for oil palm production in Ghana," European Journal of Agronomy, vol. 81, pp. 1-14, 2016.

[26] M. K. V Carr, "The water relations and irrigation requirements of oil palm (Elaeis guineensis): a review," Experimental Agriculture, vol. 47, no. 4, pp. 629-652, 2011.

[27] P. Carr, C. Nakharin, J. H. Clendon, and R. H. V. Corley, "A review of 15 years of oil palm irrigation research in Southern Thailand," Planter, vol. 84, no. 989, pp. 537-546, 2008.

[28] R. Ochs and C. Daniel, "Research on techniques adapted to dry regions," in Oil Palm Research, R. H. V. Corley, J. J. Hardon, and B. J. Wood, Eds., pp. 315-330, Elsevier Scientific Publishing, Amsterdam, Netherlands, 1976.

[29] Soil Survey Staff, Key to Soil Taxonomy, USDA-Natural Resources Conservation Service, Washington, DC, USA, 12th edition, 2014.

[30] IUSS Working Group WRB, "World reference base for soil resources 2014 international soil classification system for naming soils and creating legends for soil maps," World Soil Resources Reports No. 106, FAO, Rome, Italy, 2015.

[31] S. E. Fick and R. J. Hijmans, "WorldClim 2: new 1-km spatial resolution climate surfaces for global land areas," International Journal of Climatology, vol. 37, no. 12, pp. 43024315, 2017.

[32] V. J. Kilmer and L. T. Alexande, "Methods of making mechanical analyses of soils," Soil Science, vol. 68, no. 1, pp. 15-24, 1949.

[33] O. Epebinu and B. Nwadialo, "Predicting soil water availability from texture and organic matter content for Nigerian soils," Communications in Soil Science and Plant Analysis, vol. 24, no. 7-8, pp. 633-640, 1993.

[34] National Soil Survey Center, "Soil survey laboratory methods manual," Soil Survey Investigations Report No. 42, Version 3.0," Natural Resources Conservation Service, U.S. Department of Agriculture, Washington, DC, USA, 1996.

[35] D. W. Nelson and L. E. Sommers, "Total carbon, organic carbon, and organic matter," in Methods of Soil Analysis. Part 2. Chemical and Microbiological Properties, A. L. Page, R. H. Miller, and D. R. Keeney, Eds., vol. 9, pp. 539-579, no. Agronomy no. 9, American Society of Agronomy, Madison, WI, USA, 2nd edition, 1965.

[36] J. M. Bremner, "Nitrogen-total," in Methods of Soil Analysis. Part 3-Chemical Methods. SSSA Book Series 5, D. L. Sparks, Ed., no. 5, pp. 1085-1121, American Society of Agronomy, Madison, WI, USA, 1996.

[37] L. Nätscher and U. Schwertmann, "Proton buffering in organic horizons of acid forest soils," Geoderma, vol. 48, no. 1, pp. 93-106, 1991.

[38] H. D. Chapman, "Cation-exchange capacity," in Methods of Soil Analysis. Part 2. Chemical and Microbiological Properties, C. A. Black, Ed., pp. 891-901, American Society of Agronomy, Madison, WI, USA, 1965.

[39] G. W. Thomas, "Exchangeable cations," in Methods of Soil Analysis, Part 2, Chemical and Microbiological Properties, A. L. Page, Ed., pp. 159-165, American Society of Agronomy, Madison, WI, USA, 2nd edition, 1982.

[40] M. Peech, "Exchange acidity," in Methods of Soil Analysis. Part 2. Chemical and Microbiological Properties, C. A. Black, Ed., pp. 905-913, American Society of Agronomy, Madison, WI, USA, 1965.

[41] R. H. Bray and L. T. Kurtz, "Determination of total, organic, and available forms of phosphorus in soils," Soil Science, vol. 59, no. 1, pp. 39-45, 1945.

[42] S. M. Combs, J. L. Denning, and K. D Frank, "Sulfate-sulfur," in Recommended Chemical Soil Test Procedures for the North 
Central Region, J. R. Brown, Ed., pp. 35-40, Missouri Agricultural Experimental Station, North Central Regional Research Publication, Columbia, MO, USA, 1998.

[43] G. H. Hargreaves and Z. A. Samani, "Reference crop evapotranspiration from temperature," Applied Engineering in Agriculture, vol. 1, no. 2, pp. 96-99, 1985.

[44] P. Läderach, A. Martinez-Valle, G. Schroth, and N. Castro, "Predicting the future climatic suitability for cocoa farming of the world's leading producer countries, Ghana and Côte d'Ivoire," Climatic Change, vol. 119, no. 3-4, pp. 841-854, 2013.

[45] R. G. Allen, L. S. Pereira, D. Raes, and M. Smith, Crop Evapotranspiration-Guidelines For Computing Crop Water Requirements, Food and Agriculture Organization of the United Nations, Rome, Italy, 1998.

[46] C. W. S. Hartley, The Oil Palm (Elaeis Guineensis Jacq.), Longman Scientific \& Technical, New York, NY, USA, 3rd edition, 1988

[47] J. Shamshuddin, W. Wan Noordin, I. Roslan, C. I. Fauziah, and Q. A. Panhwar, Ultisols and Oxisols: Enhancing Their Productivity For Oil Palm, Rubber and Cocoa Cultivation, UPM Press, Serdang, Malaysia, 1st edition, 2015.

[48] K. J. Goh, "Fertilizer recommendation systems for oil palm: estimating the fertilizer rates," in Proceedings of MOSTA Best Practices Workshops: Agronomy and Crop Management, pp. 235-268, Malaysian Oil Scientists' and Technologists' Association, Selangor, Malaysia, August 2005.

[49] P. Oettli, S. K. Behera, and T. Yamagata, "Climate based predictability of oil palm tree yield in Malaysia," Scientific Reports, vol. 8, no. 1, p. 2271, 2018.

[50] C. R. Ahern, A. E. McElnea, and L. A. Sullivan, Acid Sulfate Soils Laboratory Methods Guidelines, Queensland Department of Natural Resources, Mines and Energy, Brisbane, Australia, 2004.

[51] L. A. Douglas and F. Fiessinger, "Degradation of clay minerals by $\mathrm{H}_{2} \mathrm{O}_{2}$ treatments to oxidize organic matter," Clays Clay Miner.vol. 19, no. 1, pp. 67-68, 1971.

[52] E. A. Auxtero and J. Shamshuddin, "Growth of oil palm (Elaeis guineensis) seedlings on acid sulfate soils as affected by water regime and aluminium," Plant and Soil, vol. 137, no. 2, pp. 243-257, 1991.

[53] R. D. Harter, Acid Soils of the Tropics, ECHO Technical Note, North Fort Myers, FL, USA, 2007.

[54] S. Muhrizal, J. Shamshuddin, M. H. A. Husni, and I. Fauziah, "Alleviation of aluminum toxicity in an acid sulfate soil in Malaysia using organic materials," Communications in Soil Science and Plant Analysis, vol. 34, no. 19-20, pp. 2993-3011, 2003.

[55] C. Yuan, R. Fitzpatrick, L. M. Mosley, and P. Marschner, "Sulfate reduction in sulfuric material after re-flooding: effectiveness of organic carbon addition and $\mathrm{pH}$ increase depends on soil properties," Journal of Hazardous Materials, vol. 298, pp. 138-145, 2015.

[56] A. Koelbl, P. Marschner, R. Fitzpatrick, L. Mosley, and I. Kögel-Knabner, "Organic matter decomposition during remediation of acid sulfate soils," in Proceedings of the 20th EGU General Assembly, EGU2018, vol. 20, p. 2794, Vienna, Austria, April 2018.

[57] J. B. Wehr, F. P. C. Blamey, and N. W. Menzies, "Aluminum," in Encyclopedia of Soil Science, R. Lal, Ed., pp. 105-110, CRC Press, Boca Raton, FL, USA, 3rd edition, 2017.

[58] Q. A. Panhwar, U. A. Naher, O. Radziah, J. Shamshuddin, and I. M. Razi, "Eliminating aluminum toxicity in an acid sulfate soil for rice cultivation using plant growth promoting bacteria," Molecules, vol. 20, no. 3, pp. 3628-3646, 2015.

[59] N. Supena, A. Soegianto, and L. Soetopo, "Response of oil palm varieties to aluminium stress," Journal of Tropical Life Science, vol. 4, no. 1, pp. 51-60, 2014.

[60] Y. C. Poon and C. Bloomfield, "The amelioration of acid sulphate soil with respect to oil palm," Tropical Agriculture, vol. 34, no. 4, pp. 289-305, 1977.

[61] S. Paramananthan, "Soil suitability and management implications of soil taxonomy with special reference to tree crop cultivation," Pertanika Journal of Tropical Agricultural Science, vol. 10, no. 2, pp. 125-134, 1987.

[62] S. Palykaew, A. Suddhiprakarn, I. Kheoruenromne, and N. Chittamart, "Suitability of acid sulfate soils for growing oil palm in Central Plain, Thailand," in Proceedings of 54th Kasetsart University Annual Conference: Plants, Animals, Veterinary Medicine, Fisheries, Agricultural Extension and Home Economics, vol. 1, pp. 39-46, Kasetsart University, Bangkok, Thailand, February 2016.

[63] R. R. Weil and N. C. Brady, The Nature and Properties of Soils, Person Education, London, UK, 15th edition, 2017.

[64] R. Lal, "Potential of desertification control to sequester carbon and mitigate the greenhouse effect," Storing Carbon in Agricultural Soils: A Multi-Purpose Environmental Strategy, vol. 51, no. 1, pp. 35-72, 2001.

[65] N. J. Nwosu and P. B. Okon, "Impacts of some climatic factors on soil quality of tropical acid-sand Soils," in Handbook of Climate Change Resilience, W. Leal Filho, Ed., pp. 1-23, Springer, Cham, Switzerland, 2019.

[66] V. Novák and H. Hlaváčiková, "Soil temperature and heat transport in soils," in Applied Soil Hydrology, V. Novák and H. Hlaváčiková, Eds., vol. 32, pp. 303-318, Springer, Cham, Switzerland, 2019.

[67] A. Hadas, "Heat capacity," in Encyclopedia of Soil Science, W. Chesworth, Ed., pp. 305-307, Springer, Dordrecht, Netherlands, 2008.

[68] F. Karandish and A. Shahnazari, "Soil temperature and maize nitrogen uptake improvement under partial root-zone drying irrigation," Pedosphere, vol. 26, no. 6, pp. 872-886, 2016.

[69] S. Paramananthan, "Soil properties and their influence on oil palm management and yield," in Proceedings of the Australian Centre for International Agricultural Research (ACIAR) Workshop Held in Medan, pp. 10-14, Medan, Indonesia, November 2013.

[70] J. Glinski and J. Lipiec, Soil Physical Conditions and Plant Roots, CRC Press, Boca Raton, FL, USA, 1990.

[71] R. Zornoza, J. Mataix-Solera, C. Guerrero et al., "Soil properties under natural forest in the Alicante Province of Spain," Geoderma, vol. 142, no. 3-4, pp. 334-341, 2007.

[72] H. Insam, D. Parkinson, and K. H. Domsch, "Influence of macroclimate on soil microbial biomass," Soil Biology and Biochemistry, vol. 21, no. 2, pp. 211-221, 1989.

[73] R. Alvarez and R. S. Lavado, "Climate, organic matter and clay content relationships in the Pampa and Chaco soils, Argentina," Geoderma, vol. 83, no. 1-2, pp. 127-141, 1998.

[74] C. Hontoria, A. Saa, and J. C. Rodríguez-Murillo, "Relationships between soil organic carbon and site characteristics in Peninsular Spain," Soil Science Society of America Journal, vol. 63, no. 3, pp. 614-621, 1999.

[75] P. Sarah, "Soil organic matter and land degradation in semiarid area, Israel," Catena, vol. 67, no. 1, pp. 50-55, 2006.

[76] Z. Wang, A. E. Hartemink, Y. Zhang, H. Zhang, and M. Ding, "Major elements in soils along a $2.8-\mathrm{km}$ altitudinal gradient 
on the Tibetan plateau, China," Pedosphere, vol. 26, no. 6, pp. 895-903, 2016.

[77] A. Schindlbacher, A. Rodler, M. Kuffner, B. Kitzler, A. Sessitsch, and S. Zechmeister-Boltenstern, "Experimental warming effects on the microbial community of a temperate mountain forest soil," Soil Biology and Biochemistry, vol. 43, no. 7, pp. 1417-1425, 2011.

[78] O. K. Atkin, E. J. Edwards, and B. R. Loveys, "Response of root respiration to changes in temperature and its relevance to global warming," New Phytologist, vol. 147, no. 1, pp. 141-154, 2000. 


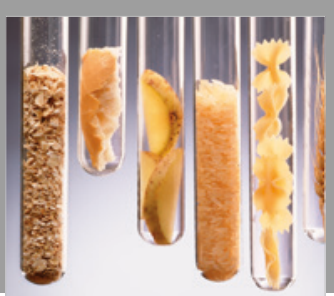

International Journal of Food Science

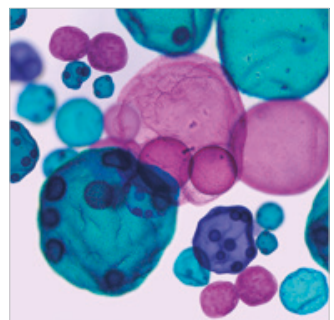

International Journal of Microbiology
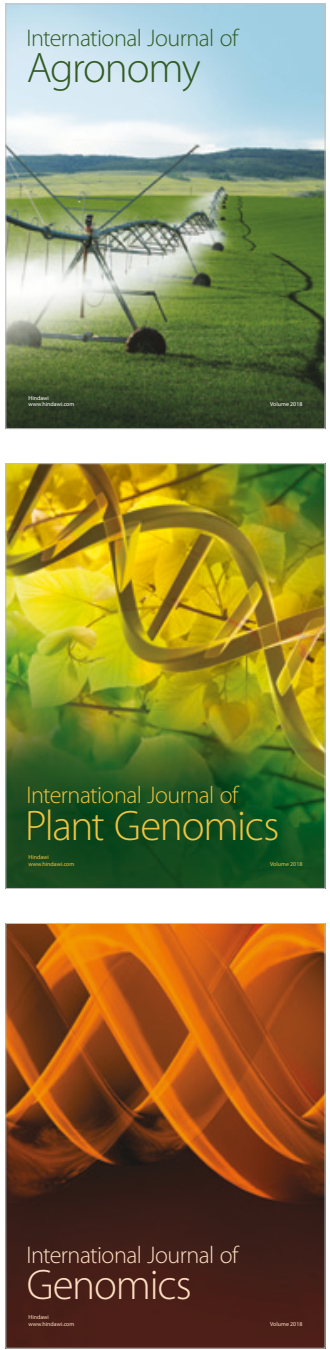

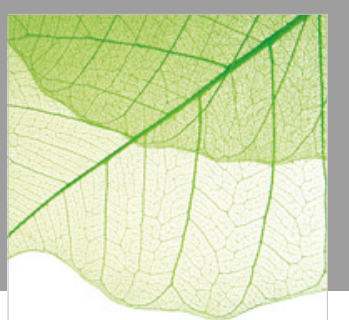

Journal of Botany
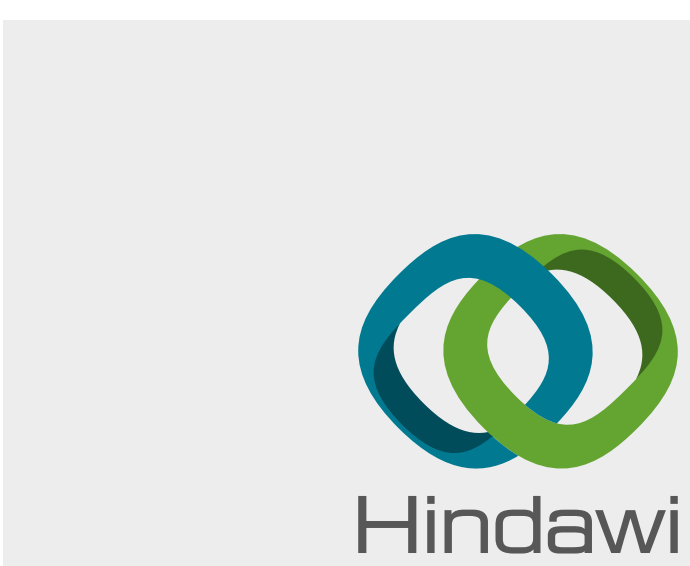

Submit your manuscripts at

www.hindawi.com
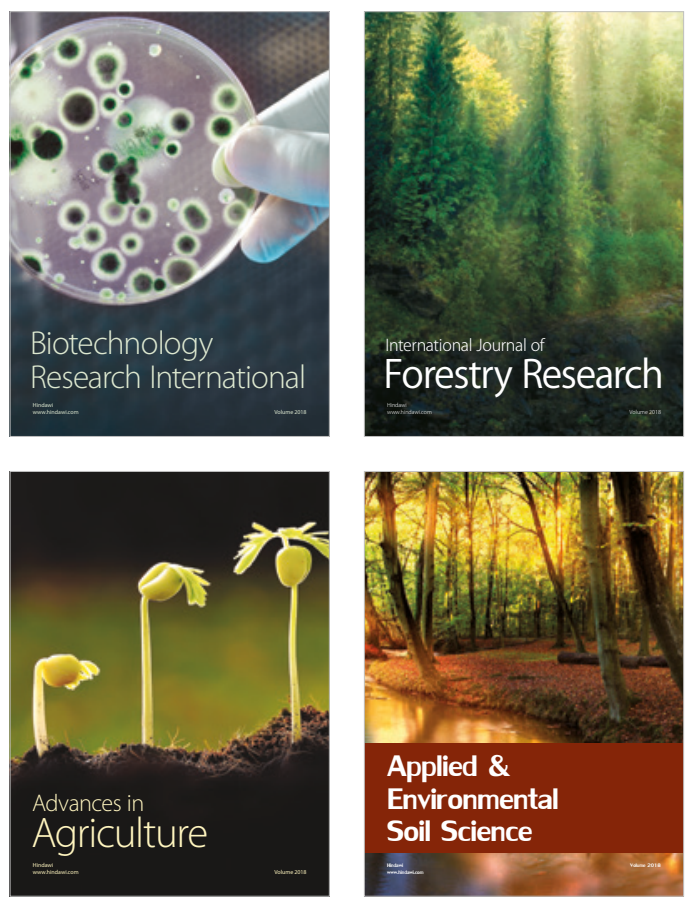

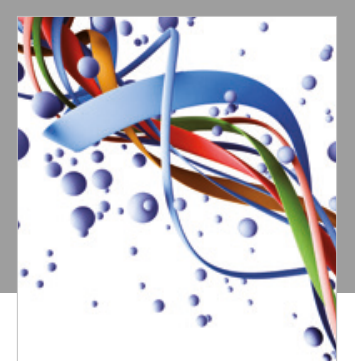

Scientifica

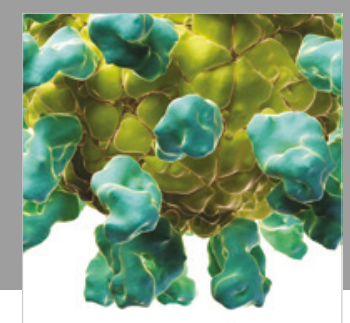

Veterinary Medicine International

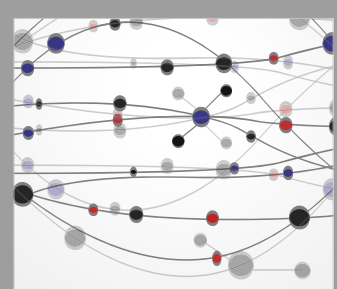

The Scientific World Journal
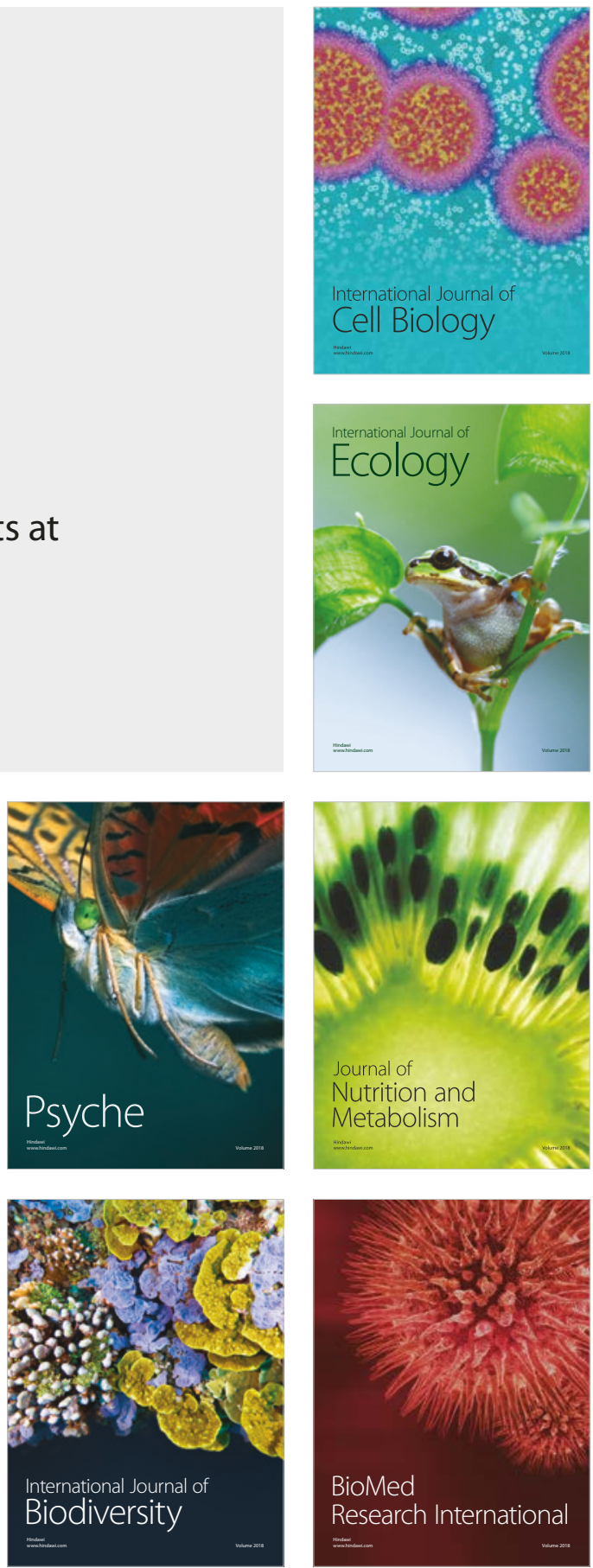